\title{
Macroseismic risk classification of historical constructions: the LEXSIS approach
}

\author{
Irene Puncello ${ }^{1}$ D $\cdot$ Silvia Caprili ${ }^{2}$ Elisa Bonanni ${ }^{3}$
}

Received: 22 October 2020 / Accepted: 16 August 2021 / Published online: 21 September 2021

(C) The Author(s) 2021

\begin{abstract}
The present paper deals with the elaboration of a methodology to assess the macro-seismic risk of monumental historical buildings, representing a fundamental part of the European cultural assets. Monumental buildings typically arise from a very complex constructive and morphological evolution process characterised by modifications occurred over the centuries. Therefore, they are usually heterogeneous buildings similar to 'structural aggregates' rather than single constructions and characterised by a structural behaviour depending on the mutual interaction of different structural units. An accurate knowledge process can allow the determination of structural units within the complex: such units can be therefore analysed using a specific evaluation form conceived to provide a 'risk ranking' of the different portions constituting the aggregate and accounting for vulnerability, exposure and seismic hazard parameters. The proposed methodology exploits what is already used to quickly determine structural features and eventual damages in the post-earthquake phase for ordinary buildings, introducing specific aspects typical of historical-cultural heritage requiring attention. According to the results achieved, retrofit interventions or deepen investigations can be planned for units provided by a higher position in the risk scale, optimising and rationally planning the use of available economic and time resources. In the present work, the proposed methodology is applied to the monumental complex of the Certosa di Calci, Pisa (Italy).
\end{abstract}

Keywords Monumental complex · Historical building $\cdot$ Macroseismic classification · Seismic risk

Irene Puncello

irene.puncello@ing.unipi.it

Silvia Caprili

silvia.caprili@ing.unipi.it

1 Department of Energy, Systems, Territory and Construction Engineering (DESTeC), University of Pisa, Pisa, Italy

2 Department of Civil and Industrial Engineering (DICI), University of Pisa, Pisa, Italy

3 Freelance engineer, Pisa, Italy 


\section{Introduction}

The seismic vulnerability of existing constructions is a well-known issue because of the widespread damages and collapses caused by recent earthquakes (Borri et al. 2017; Sevieri et al. 2020). Together with their unavoidable social consequences, human and economic losses strongly encouraged research activities concerning seismic risk evaluation. The seismic risk is defined as the probability of exceedance of a specific level of economic, social or environmental losses in a particular site within a specified reference period and due to a given intensity earthquake (Lantada et al. 2010). The seismic risk can be therefore seen as the convolution of three main factors: (1) a seismic hazard model representing the earthquake probability, (2) a set of functions able to describe the building vulnerability and representing the damage probability, given the earthquake, (3) a parameter indicating the exposure of considered elements representing the probability of loss, given the damage. Particularly, the loss can be differently expressed (e.g. with reference to the number of dead, repair cost, loss of functions) depending on the analysed situation (Pasquale et al. 2005). This definition, first proposed within the report Natural Disasters and Vulnerability Analysis (UNDRO 1980) after the Expert Meeting held in 1979, was improved during the years to face the needs and shortcomings highlighted by the occurred seismic events (e.g. Molise 2002, L'Aquila 2009, Emilia-Romagna 2012 and Centro Italia 2016) (Braga et al. 2017).

Different complexity-degree approaches can be nowadays adopted to specify each of the above-mentioned parameters for the overall seismic risk scenario. Many studies developed in the current and past scientific literature dealing with their specific role in seismic risk assessment (to mention only a few: Silva et al. 2015; Kalman Šipoš and Hadzima-Nyarko 2017; Silva et al. 2014; Wieland et al. 2014). But, when speaking about monumental buildings, the vulnerability parameter-directly related to the high complexity of the construction typology - can predominate over the others (whose evaluation is, in any case, necessary), therefore requiring particular attention.

At the Italian national level, the first systematic researches concerning vulnerability date back to the ' $80 \mathrm{~s}$, as a consequence of the Friuli and Irpinia events in 1976 and 1980, highlighting the need for seismic risk assessment on a wide territorial scale (Braga et al. 1982; Guagenti et al. 1988; Yang et al. 1989; Pasquale et al. 2005; Zuccaro and Cacace 2015). For instance, the statistical analysis of the damages associated with the Irpinia earthquake allowed the development of a procedure based on Damage Probabilities Matrix (DPM) where vulnerability classes were defined depending on the vertical and horizontal structural typologies, assuming for a given typology the same probability of reaching a specific damage state for a given seismic intensity. For each class, a binomial distribution-i.e. parameters in the range $0 \div 1$-was introduced to describe the damages for different earthquake intensities (Braga et al. 1982). Other studies adopting DPM were developed basing on collected data (e.g. Barbat et al. 1996; Dolce et al. 1996; Di Pasquale and Orsini 1997; Zuccaro et al. 2000; Bernardini and Lagomarsino 2008) or using the approach proposed by the European Macroseismic Scale EMS98 (Grünthal 1998; Giovinazzi and Lagomarsino 2004; Bernardini et al. 2007). Starting from Giovinazzi (2005) and Lagomarsino and Giovinazzi (2006), the procedure proposed by Braga et al. (2017) represents a further improvement defining a loss-curve relating the economic losses in terms of Expected Annual Loss to the seismic intensity, adopting the EMS98 definition for vulnerability classes. Again, Benedetti et al. (1986) proposed a seismic vulnerability analysis through the Vulnerability Index Method: a field survey form with vulnerability parameters associated with a score 
and a weight depending on the quality conditions was elaborated, providing a global index accounting for all the contributions. Survey forms were proposed even within the GNDT II level method (GNDT-SSN 1994) for existing masonry and reinforced concrete constructions, providing a vulnerability index based on post-seismic damages' observations concerning geometric and structural features. Starting from GNDT II method, further approaches developed focusing on historical city centres, relevant issue of the Italian national territory: Formisano et al. (2010) and Vicente et al. (2011) introduced specific parameters accounting for the aggregate effect on adjacent structural units. Ferreira et al. (2017) provided further developments to the Vicente et al. (2011) method by re-calibrating the vulnerability parameters (e.g. structural system, irregularities and interactions, floor slabs and roofs, maintenance condition, non-structural elements) basing on the damages surveyed in the Azores.

All the above-mentioned methods provided quick and easy classification tools for specific buildings' typologies (e.g. reinforced concrete or ordinary masonry buildings, in-row masonry buildings, etc.) based on a statistical/observational approach of damages; their easiness became, in the meanwhile, their limit, being hardly applicable to constructions with different features respect to the ones used for the calibration of the forms.

The current scientific literature also proposes mechanical methods to assess the seismic vulnerability of existing constructions, depending on the adoption of numerical models able to represent - with different degrees of complexity - the building structural behaviour. Obviously, the higher is the accuracy and complexity of the model, the higher is the computational effort required to analyse and assess the construction's condition (Zuccaro and Cacace 2015). To cite a few, the procedures proposed by Dolce and Moroni (2005) - the SAVE method, by Chinni et al. (2013) - the RE.SIS.TO procedure, the FAMIVE method elaborated by D'Ayala and Speranza (2002) and many others (Bernardini 2000; Lourenço and Roque 2006; Lourenço et al. 2013, etc.) can be mentioned.

If methodologies for vulnerability assessment exist dealing with different structural typologies, the introduction of parameters concerning the area seismic hazard level allows the shift to a risk perspective: several studies are proposed to assess the seismic risk level of a specific site (e.g. Vicente et al. 2011; Chaulagain et al. 2015; Eleftheriadou et al. 2014; Jalayer and Ebrahimian 2017; D'Amato et al. 2018; Novelli and D'Ayala 2019; Quagliarini et al. 2019, etc.), also accounting for real losses related to exposure. Therefore, seismic risk management increasingly gained a fundamental role in urban planning, being relevant for the determination of the most vulnerable buildings within the analysed area and allowing to organise mitigation/retrofit measures according to a cost-benefit overview (Ferreira et al. 2017; Neves et al. 2012). The seismic risk assessment can be considered as a tool to manage the conservation planning for monumental historical constructions, characterised by high complexity, relevance from an architectural, historical and maintenance point of view and therefore needing specific attention during the evaluation process.

Being characterised by a non-homogeneous construction process due to following transformations, modifications and aggregations over the centuries (Valluzzi et al. 2006), monumental buildings can be defined as 'Structural aggregates' (SA). They appear as composed by several 'Structural Units' (SU) (Lagomarsino et al. 2014; Caprili et al. 2017; Degli Abbati et al. 2018) working together for the overall performance and deeply interacting, determining a resulting behaviour where the influence of each SU becomes relevant (Degli Abbati et al. 2018). The seismic risk assessment of a monumental complex represents a fundamental 'conservation tool' since the results allow identifying the units needing primarily more in-depth analysis. Therefore, retrofit interventions can be consciously organised, succeeding in the accurate management of economic resources (Sivieri et al. 2020). 
In the present work, a relatively rapid method for the macroseismic risk assessment of a monumental complex - intended as the aggregation of different structural units-is proposed and applied to a specific case study building. Since monumental complexes appear as very complicated structures with a lot of heterogeneities, several investigations are required to reach even a (relatively) limited knowledge needed to apply the method. Therefore, the definition of the present method as 'rapid' is valid when compared to in-depth numerical analyses requiring a high-accurate knowledge level considerably time and money demanding.

The core of the methodology is the disaggregation of a monumental complex in its SUs, in accordance with the information coming from the reconstruction of the morphological evolution of the complex and with data coming from in situ surveys and investigations on materials and structures (Munari et al. 2010; Carocci 2012; Castori et al. 2017). Once ideally decomposed the compound, it is possible to deal with it such as with a small urban aggregate, therefore, resorting to a macroseismic approach. The elaboration of a specific form (the LEXSIS form), able to collect all relevant structural, morphological, exposure and hazard information, is proposed and applied to each recognised SU. Concerning the vulnerability, the form based on what suggested by the current scientific literature (GNDT-SSN 1994, Formisano et al. (2010) and Vicente et al. (2011)) for other masonry building categories, by adding specific additional features typical for monumental high-complexity constructions, and proposing a floor-by-floor evaluation accounting for the typical construction process of such building typology. Simplified considerations concerning exposure and seismic hazard are then added compared with the above-mentioned sources to provide a macroseismic risk evaluation. In particular, the exposure is determined with reference to the specific use of spaces and the related imposed live loads, while the hazard parameter is defined through the peak ground acceleration values.

The application of the proposed procedure and the filling in of the form for each identified SU lead to the evaluation of a number of risk indexes. The indexes are not meant to be meaningful in absolute terms since no comparisons with thresholds values are defined: they are instead helpful in relative terms, allowing the comparison of the results within the framework of the SA and determining an internal risk ranking. Such an achievement gives useful indications about the priorities within the SA, indicating the more urgent critical issues to be faced and related interventions to be planned or, otherwise, about the possibility of extending over time what is not strictly necessary.

Filling in the form bases on the expert's opinion: this means that even if a slight variability characterises each parameter depending on the personal judgment of the technician, the higher is the knowledge accuracy, survey, etc. the higher will be the reliability of the result, reducing the uncertainty related to the parameter qualification (Vicente 2008). Therefore, the outcome will be not as accurate as that achievable through numerical approaches - considerably much more time and money demanding but can provide a first rapid screening of the situation based on expert evaluation.

In the present paper, the LEXSIS forms are applied to the monumental complex of Certosa di Calci (Pisa, Italy). Of course, several aspects of the method needed to be adapted to the specific structure of this SA, but the applied approach is otherwise of general application, being therefore easily adapted to other structures as well. 


\section{Methodology for macro-seismic risk classification}

Four main steps (Fig. 1) compose the methodology proposed for the macro-seismic risk classification of monumental structural aggregates (SA), namely (1) the knowledge analysis, (2) the identification of structural units inside the complex, (3) the elaboration and application of a quick evaluation form to be applied to every single structural unit and (4) the achievement of a risk hierarchy.

For the sake of clarity, it shall be marked from the beginning that the risk hierarchy achieved as the final step of the methodology is meant to provide a list of priorities regarding the SUs composing the monumental aggregate, identifying the SUs on which primarily focus more in-depth investigations and analyses (e.g. detailed linear or nonlinear analyses on FEM models). Otherwise, the risk index achieved for each SU should not be considered in absolute terms, being based on a qualitative and not quantitative parameter evaluation: this is the reason why any threshold value has been defined for correlating the index achieved with the unconditioned need of retrofitting projects. Similarly, comparing the results achieved for SUs belonging to different monumental aggregate, even if applying the same described methodology, appears meaningless.

\subsection{Knowledge analysis}

The knowledge analysis is necessary to overcome the general lack of information characterising historical buildings (CdM 2011). Data concerning the morphological evolution, geometrical characteristics, and structural and architectural features are needed to recognise the structural units inside the aggregate and achieve reliable and meaningful results. The critical/historical analysis helps in understanding the building's construction phases: monumental structures are the result of a long and complicated process, usually not fully known or properly recorded, direct response to functional and architectural needs (Lagomarsino 2006; Caprili and Puncello 2019; Ramírez et al. 2019). This procedure determines the non-homogeneous areas within the building, associating — where possible — each portion/structural component to a specific construction phase, checking the assumptions' reliability through detailed investigations. The in-situ surveys collect information concerning all the relevant aspects for the seismic risk evaluation and the full understanding of the structural morphology.

Attention shall be paid to the building's geometry, the floors' and walls' alignments and regularity aspects - in plan and in elevation — of the bearing structures. The floors' typology as well as the masonry textures and, where possible, the wall consistency need to be investigated together with the cracking patterns, the presence of out-of-plumb deformations and all the other possible deterioration phenomena representing an essential database of the structural behaviour (Dogangun and Sezen 2012, Fuentes et al. 2019). The

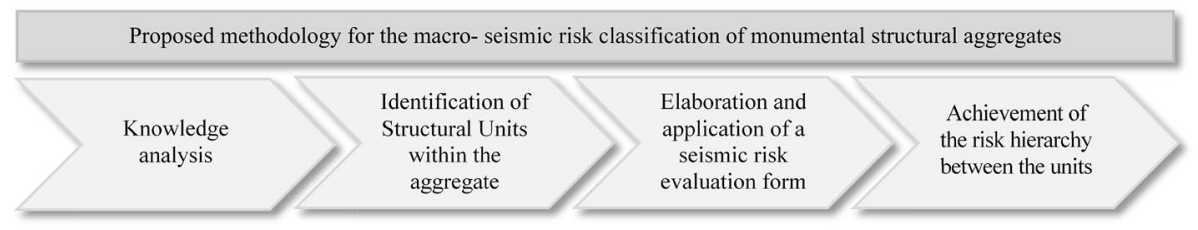

Fig. 1 General scheme of the proposed methodology 
presence and location of non-structural components possibly constituting global or local vulnerabilities shall be also accounted for (Binda et al. 2007; Munari et al. 2010; Carocci 2012; Rainieri et al. 2013; Kržan et al. 2015; Clementi et al. 2016; Castori et al. 2017). Any other information concerning materials, foundation system, typology and properties of the ground soil, problems of water regulation of the settlement, etc., can also be useful to increase the whole SA's knowledge level.

Different knowledge levels can be generally achieved depending on the building's general complexity, the accessibility of its spaces and, above all, the economic and time resources allocated to this aim. The possibility of performing at least visual inspections within most of the building is mandatory for the proposed methodology to collect enough data for the structural disaggregation and the following filling-in of the macroseismic form. The achieved information level should be as homogeneous as possible within the building, providing a reliable comparison of the results achieved for the identified SUs. Due to the large dimensions of monumental buildings and to the high economic effort required, the definition of different knowledge levels within the monumental aggregate may be needed, leading to a more refined subdivision of SUs in those areas characterised by better accuracy of investigations, as explained in the following.

\subsection{Identification of structural units within the aggregate}

The knowledge process allows identifying the SUs constituting the SA and generally defined as 'homogeneous building's portions'. A SU can have continuity along with the vertical development of an aggregate portion (i.e. it can include all the floors in a limited structure portion), or it can be limited to a single (or a few) floor in case of big differences or evident structural discontinuities (e.g. superelevation realised with different construction systems).

As said, according to the knowledge level achieved within the complex, the adoption of a higher or lower refined subdivision in the identification process is possible.

Due to the high variability of monumental buildings' characteristics, any strict rules to be applied to all the situations can be supplied for the SUs' identification. A sort of guideline can be outlined to be filtered through the general knowledge acquired by the technician for the analysed case.

The morphological evolution usually determines the first splitting: the macro-construction phases are identified and used as starting disaggregation criterion. Portions of the complex realised almost during the same period are, in fact, probably characterised by the same construction techniques, materials and structural features. Starting from this initial subdivision, other information from the inspections and in-situ investigations is used as 'identification parameters' for the disaggregation refinement-e.g. misalignments, interfloor height, changes in walls' thickness, the technological system adopted and material typology-(Carocci 2012; Formisano et al. 2010; Munari et al. 2010; Orlando et al. 2019; Vicente et al. 2011).

Sub-units can be recognised within particularly complex SUs, characterised by high variability of the structural/geometrical features often related to a chaotic evolution process or to the compresence of different construction typologies and functional destinations. The creation of Sub-units instead of Units underlines the existence of similarities and common evolution within the different identified portions.

The high complexity of monumental buildings makes it almost impossible to reach the 'overall' homogeneity of the listed parameters within the whole SU. A general homogeneity 
can be otherwise pursued as a compromise between the coherence of the parameters and the structural reliability of the subdivision. Indeed, little uncertainties concerning the exact limit of a SU can exist at this analysis stage since based on a rather basic level of knowledge analysis. Such uncertainties will not considerably affect the results because leading, in the worst scenario, to the unperfect delimitation of the higher-risk area requiring deeper investigations. The following and more detailed step (e.g. FEM model and analysis) will require deepening the knowledge, therefore optimising the first-adopted subdivision.

\subsection{Elaboration and application of a seismic risk evaluation form}

The elaboration of a simple and rapid tool for the macro-seismic risk classification allows the easy analysis of the SA subdivided into SUs, accounting for differences and heterogeneities - if existing —otherwise neglected. A structured form—the LEXSIS form—was developed for historical masonry buildings based mainly on the procedure introduced in 1993 by the Italian National Group for Earthquake Defence (GNDT-SSN 1994). Several sections compose the form, accounting for general data identifying the SUs within the SA, together with the assessment of vulnerability, exposure and seismic hazard, finally providing a resulting SU Risk Index $\left(I_{S U}\right)$, as described in the following.

The complex vulnerability is determined through the detailed analysis of structural and geometrical information coming from the in-situ survey. According to the intended use, the number of expected people in the different spaces is instead considered for the exposure parameter: this means that the human loss has been indirectly accounted for in a simplified way. Despite dealing with historical constructions, the loss related to the cultural value was not included within the exposure parameter. The cultural value lies, in fact, in the whole monumental compounds and cannot be evaluated by considering the different SUs as isolated: the whole complex's cultural value is necessarily higher than that possibly associated with the SUs and is not divisible.

Data deriving from the seismic micro-zonation and, particularly, the possible different PGA values achieved within the aggregate site can be used to assess the seismic hazard; when lacking seismic micro-zonation, such as in the presented case study, the hazard can be assumed homogeneous within the aggregate.

In the LEXSIS approach, the SU vulnerability is evaluated by analysing each floor separately and its relative structural and critical features, re-assembling them together accounting for a 'weight' mainly depending on dimensions. As typical for monumental buildings, a wide heterogeneity is evident even comparing different floors within the same SU: this comes from the morphological evolution process, characterised by enlargements and superelevations realised through new plan/new storey addition with different structural, material, geometrical and functional features. Analysing all the floors together without introducing adequate differentiation will lead to neglect of relevant/critical elements, providing too general (and somewhat useless) results.

\subsection{Risk hierarchy between the units}

Finally, by comparing the risk indexes $\left(I_{S U}\right)$ achieved for each of the units/sub-units identified within the SA, a 'risk hierarchy' between the SUs useful for planning mitigation interventions and for the optimisation of time and economic resources' management is provided. Of course, possible variations in the knowledge level achieved for different portions of the SA shall be accounted for, adopting-for instance-two or more risk rankings with 
the aim of not altering relevantly the results. The comparison of the results in terms of risk index is recommended between units characterised by similar information detailed, consequently defining two or more risk rankings.

\section{The LEXSIS form}

The LEXSIS (compLEX construction macroseismic analySIS) tool, proposed for the seismic risk analysis of monumental buildings, is organised in five different sections. The first is for identification purposes and is not associated with any score, the second and third determine the vulnerability index $\left(I_{V}\right)$, the fourth is related to the exposure index $\left(I_{E}\right)$, and the last one concerns the seismic hazard $\left(I_{S h}\right)$, as summarised in the following:

- Section 1 - Identification: summarises data useful to identify the considered structural unit (SU) providing the overall overview of the work. A small plan is provided to locate the $\mathrm{SU}$ within the aggregate (SA).

- Section 2 - SU General vulnerability: gives general information concerning the regularity in plan and elevation of the considered SU, such as the unit shape (i.e. the ratio among the sides of the rectangle circumscribing the planimetry, the maximum values of indentations or protrusions, the reduction of the horizontal section), the uniform/ non-uniform distribution of masses and stiffness resulting from the presence of irregularities due to non-structural elements such as infill panels, etc.

- Section 3 - SU Floors' vulnerability: evaluates, separately as said before, the vulnerability of each floor, including the roof. Information concerning vertical and horizontal structures (e.g. architectural features, materials, structural typology, presence of strengthening devices, presence of cracks or other degradation phenomena possibly related to the activation of local mechanisms, etc.) are provided. The presence of partition walls is further considered, accounting for their distribution, for the consequences of their positioning (i.e. creation of short pillar effect) and for their continuity along the vertical direction (this aspect is connected to the regularity information provided by Section 2).

- Section 4 - Exposure: defines the exposure-related aspects concerning the number of people that the earthquake event's effects can directly strike. The problem is, of course, not of easy determination: to simplify it, exposure can be traced back to the intended functional destination of the considered building/floors/rooms etc.

- Section 5 - Seismic Hazard: evaluates the site seismic hazard using specific PGA values coming, if present, from a seismic micro-zonation analysis.

\subsection{Vulnerability index (IV)}

Each parameter considered in the SU description (Table 1), e.g. regularity, material typology, storeys, etc.) is associated with a global 'phenomenon score'. Such score is determined first by accounting for the analysed parameter's presence (or lack) and later applying a weight considering its extension and severity within the SU.

More precisely, the presence/lack is expressed through the parameter $P$ having a value different from zero when the phenomenon is detected within the SU or otherwise being equal to zero, as specified in Table 1 . The extension $\left(w_{e}\right)$ and severity $\left(w_{s}\right)$ weighting factors are divided into five classes (Tables 2 and 3), allowing to 'judge' in a simplified and 
Table 1 Scored assigned to the vulnerability parameters

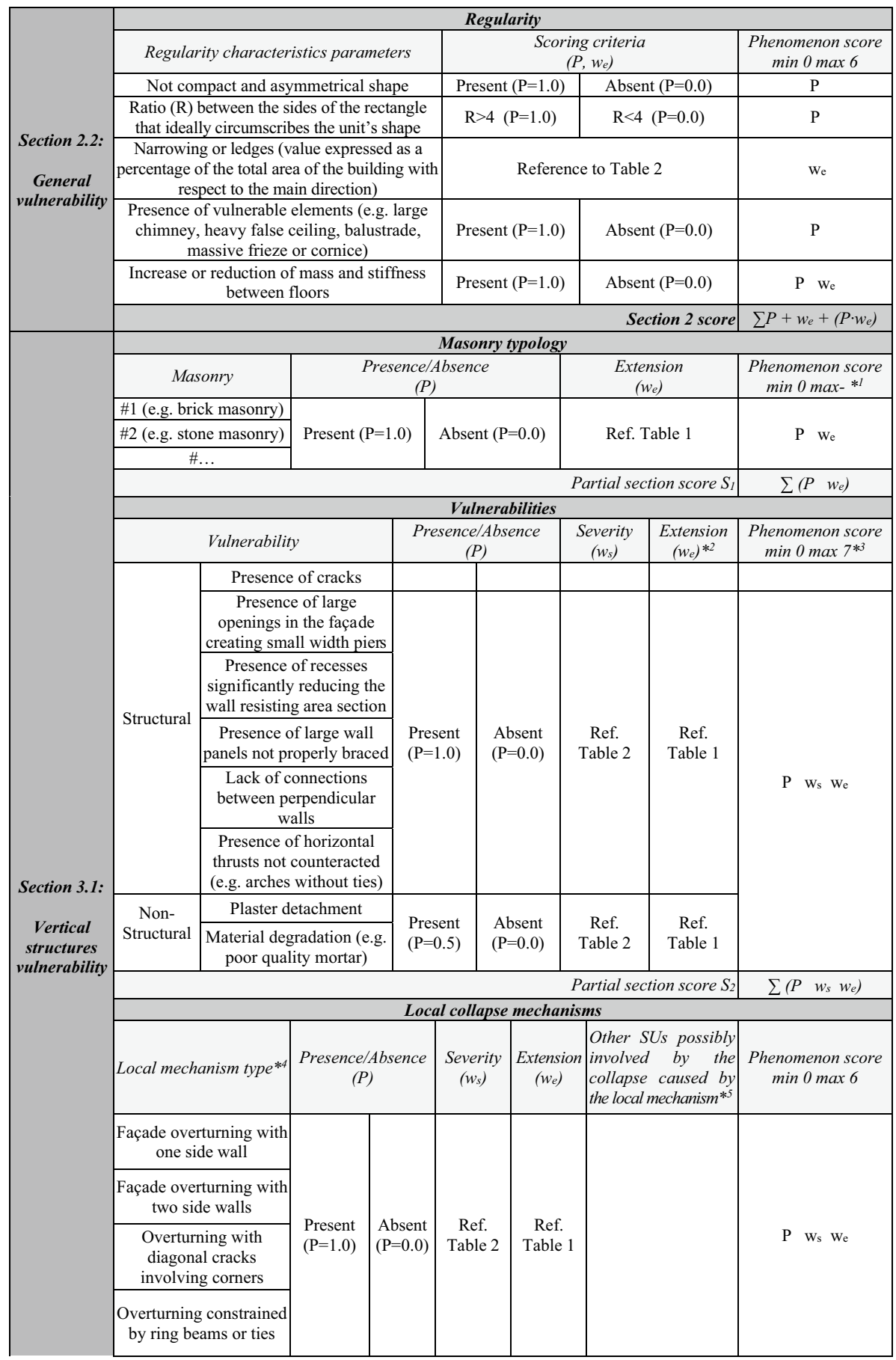


Table 1 (continued)

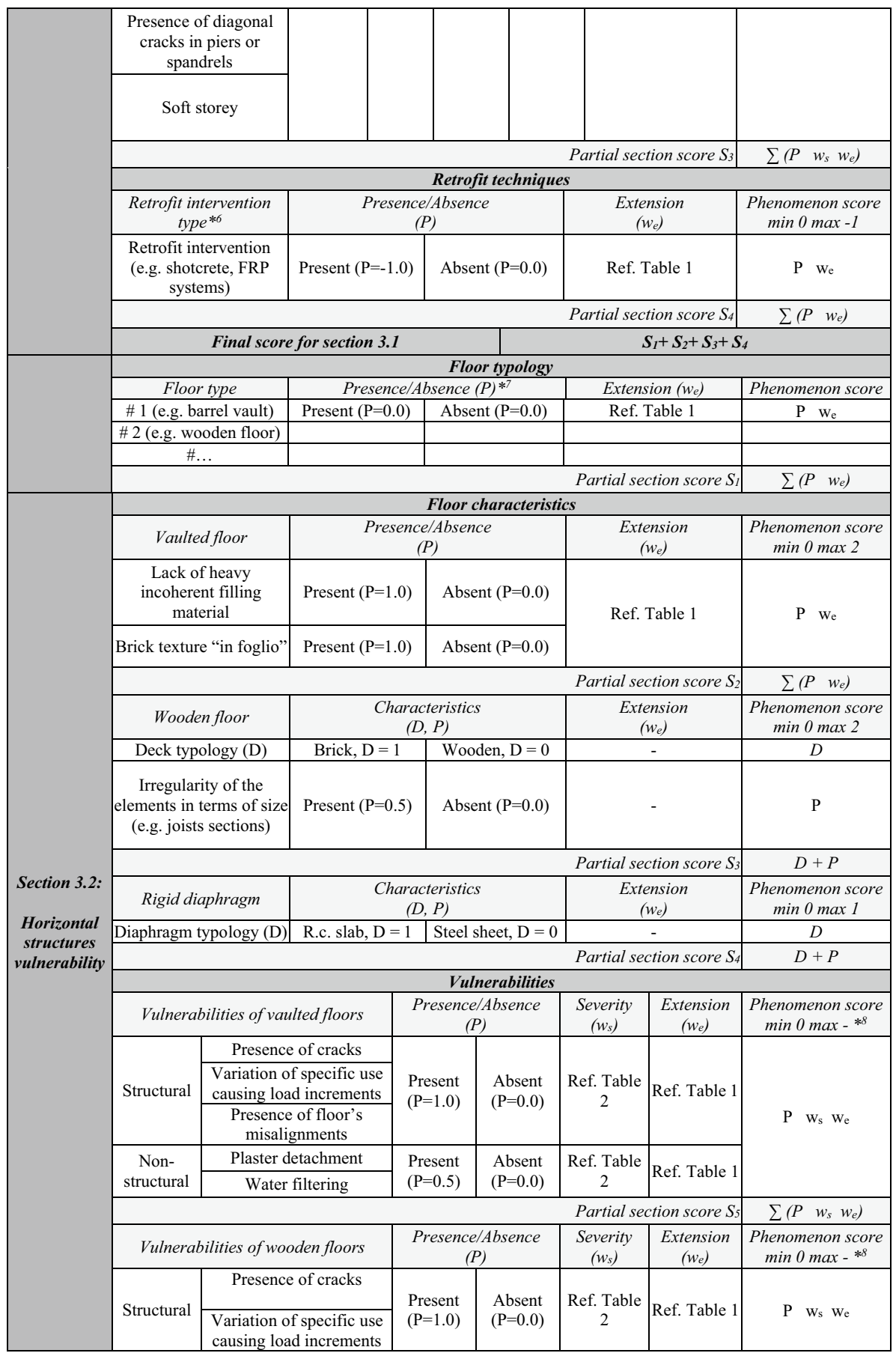


Table 1 (continued)

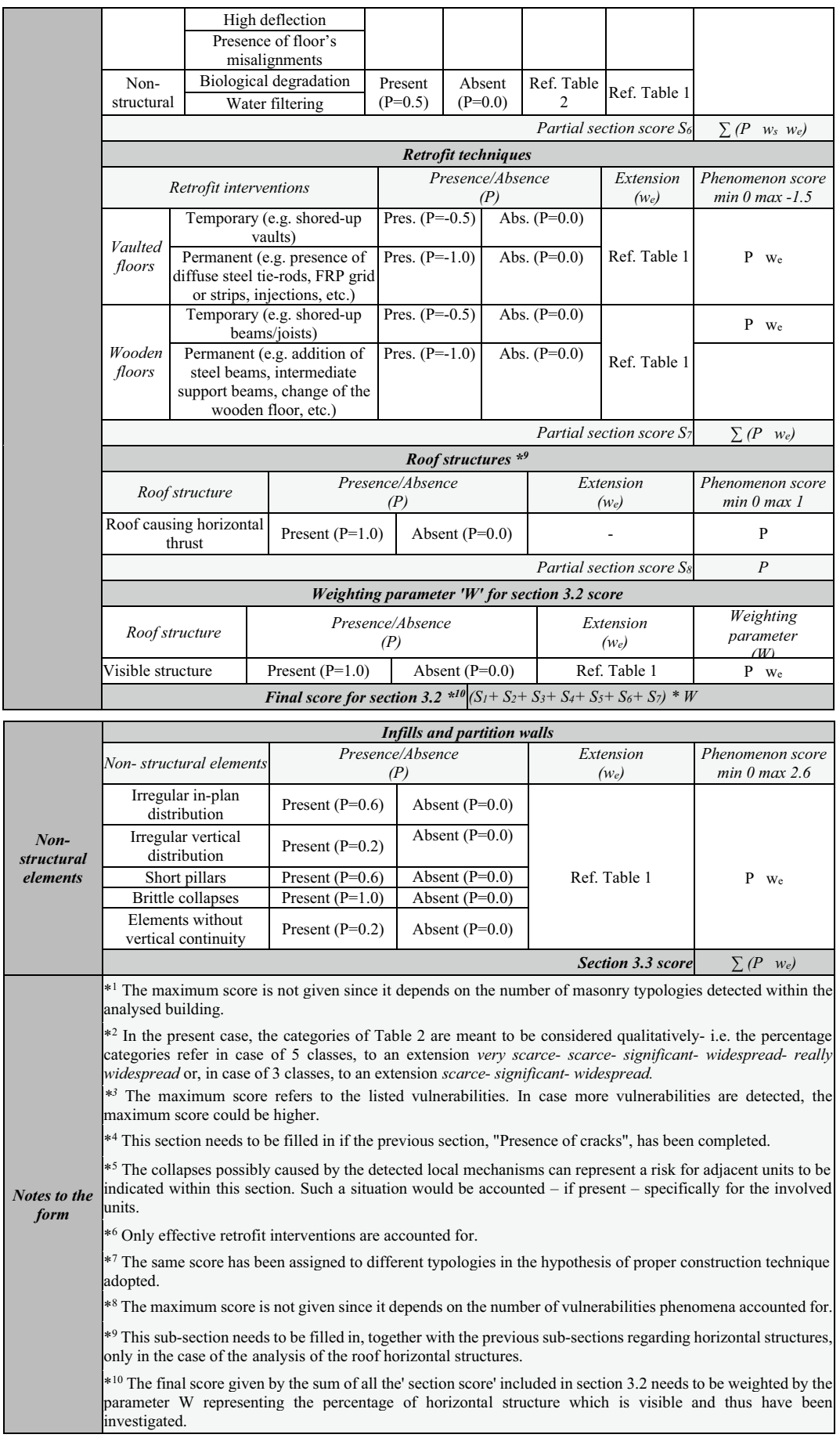


Table 2 Weight associated with the 'extension' parameter

\begin{tabular}{lll}
\hline Extension & $\begin{array}{l}\text { Extension percentage per floor } \\
(\%)\end{array}$ & $\begin{array}{l}\text { Associated } \\
\text { weight } \\
\left(\mathrm{w}_{\mathrm{e}}\right)\end{array}$ \\
\hline Class & $0-10$ & 0.2 \\
Class 1 & $11-30$ & 0.4 \\
Class 2 & $31-50$ & 0.6 \\
Class 3 & $51-80$ & 0.8 \\
Class 4 & $81-100$ & 1.0 \\
Class 5 & & \\
\hline
\end{tabular}

\begin{tabular}{lll}
\hline Severity & & \\
\hline Class & Severity level per floor & $\begin{array}{l}\text { Associated } \\
\text { weight }\left(\mathrm{w}_{\mathrm{s}}\right)\end{array}$ \\
\hline Class 1 & Very small & 0.2 \\
Class 2 & Small & 0.4 \\
Class 3 & Moderate & 0.6 \\
Class 4 & Serious & 0.8 \\
Class 5 & Very serious & 1.0 \\
\hline
\end{tabular}

Table 3 Weight associated with the 'severity' parameter

intuitive way the influence of the analysed parameter. In particular, $w_{e}$ represents how much the phenomenon is widespread within the examined floor while $w_{s}$ indicates its relevance. Each parameter's vulnerability contribution can be determined case by case by considering only one factor among extension and severity, or the combination of the two, depending on the nature of the phenomenon.

Starting from the above-mentioned considerations, the phenomenon vulnerability $\mathrm{I}_{p}$ can be evaluated according to Eq. (1):

$$
I_{p}=P \cdot w_{e} \cdot w_{s}
$$

The global vulnerability index $\left(I_{V}\right)$ of the SU, as expressed in Eq. (2), is then achieved by adding all the single evaluated $\mathrm{I}_{p}$.

$$
I_{V}=\sum I_{p}
$$

In presence of beneficial effects (e.g. retrofit interventions like ties, chains, etc.), the resulting index is decreased by subtracting from the sum the relative contribution (i.e. the contribution has a negative sign, as presented in Table 1). Further normalisation can be later introduced to make easier the presentation of the results.

Table 1 summarises all the parameters considered for the calculation of the vulnerability index and the relative scores. In particular, 'global' parameters referring to SU are collected in Section 2 'SU General vulnerability' and provide a first partial vulnerability score related to the whole considered SU ('Section 2 score' in Table 1). Section 3 'SU Floor vulnerability', on the other hand, contains factors concerning vertical structures, horizontal structures and non-structural elements evaluated' floor-by-floor, whose contribution are finally summed up. The organisation of Section 3 reflects the hierarchical deconstruction 
of the building structure in the main structural systems (i.e. vertical structures, horizontal structures and non-structural elements). Each of them is described through the sub-sections referring to typology, vulnerability, local collapse mechanisms (with reference only to the vertical structures), and retrofit interventions (Novelli and D'Ayala 2015).

Concerning the masonry typology (Section 3.1 of the form), the values associated with each type's presence can vary in the range $0-1$ based on considerations coming from insitu investigations and, where available, mechanical properties. Intermediate values can be determined accounting for differences in thickness, texture regularity, typology of elements, etc.

Regarding the floors (Section 3.2 of the form), the same score was preliminarily assigned to different typologies (i.e. with wooden, steel, concrete elements, etc.) in the hypothesis of proper construction technique adopted. Of course, differences can be introduced accounting for relevant differences-when present-and in case of correct information available. The score of all the horizontal structures is weighted based on the percentage of visible structures. In the case of roof structures, the same parameters listed for horizontal floors are considered, adding the one accounting for the possibility of causing horizontal thrust.

Within the "local mechanisms" parameter (Section 3.1 of the form), the presence of in-plane and out-of-plane local mechanisms is considered, basing on the analysis of the surveyed cracking pattern such as performed in the current scientific literature (Bosiljkov et al. (2015), Novelli and D'Ayala (2019) just to cite just few). Moreover, the presence of adjacent SUs possibly damaged by the collapse potentially caused by the local mechanism is highlighted to monitor the situation (induced external risk).

The aggregate effect-i.e. the interaction phenomena between SUs influencing the structural performance- - has been neglected at this stage. Despite being a relevant issue for monumental aggregates, no effective solutions accounting for it in a simplified and reliable way have been found due to the complexity of the analysed building typology. Dealing with a sort of preliminary analysis level, this approximation is considered reasonable. Once identified the SUs to be more urgently in-depth investigated and analysed, the interaction effects can be accounted for by means of more sophisticated strategies (e.g. complex FEM models).

\subsection{Exposure index (IE)}

The exposure index $\left(I_{E}\right)$ was evaluated based on the specific use, i.e. the higher is the expected number of people for the specific location, the higher is the associated score $\left(I_{u}\right)$. The final index was obtained by multiplying, for each floor, the score mentioned above and the percentage extension of the areas $\left(E_{\%}\right)$ characterised by the adopted $\mathrm{I}_{\mathrm{u}}$ within the SU's floor (Eq. 3).

$$
I_{E}=\sum I_{u} \cdot E_{\%}
$$

For instance, referring to the imposed live loads associated with different specific uses according to European Technical Standard for construction EC1 (EN 1991-1-1) and, for greater detail, to the national technical annexes, the scoring method proposed in Table 4 can be used. Categories of imposed live load associated with the same $I_{u}$ were grouped within the same $\mathrm{E}_{\%}$. 
Table 4 Score assigned to the exposure parameters

\begin{tabular}{|c|c|c|c|c|c|c|c|}
\hline $\begin{array}{l}\text { Category of } \\
\text { imposed load }\end{array}$ & A & $\mathrm{B} 1 *$ & $\mathrm{~B} 2 *$ & $\mathrm{C} 1-\mathrm{C} 5$ & D1-D2 & E1-E2 & H-I-K \\
\hline Specific use & Residential & Offices & $\begin{array}{l}\text { Offices open to } \\
\text { public }\end{array}$ & $\begin{array}{c}\text { Possibly } \\
\text { crowded spaces }\end{array}$ & $\begin{array}{l}\text { Commercial } \\
\text { spaces }\end{array}$ & $\begin{array}{c}\text { Storage areas } \\
\text { for commercial } \\
\text { and industrial } \\
\text { uses }\end{array}$ & Roofs \\
\hline Ref. Standard & $\mathrm{EC} 1$ & $\begin{array}{c}\text { EC1 + Italian } \\
\text { National Annex }\end{array}$ & $\begin{array}{c}\text { EC1 + Italian } \\
\text { National Annex }\end{array}$ & $\mathrm{EC} 1$ & $\mathrm{EC} 1$ & $\mathrm{EC} 1$ & $\mathrm{EC} 1$ \\
\hline \multirow{2}{*}{$\begin{array}{l}\text { Presence or } \\
\text { absence }\end{array}$} & & $\begin{array}{l}\text { ent } \\
0.4\end{array}$ & $\begin{array}{l}\text { Present } \\
I_{u}=0.6\end{array}$ & \multicolumn{2}{|c|}{$\begin{array}{c}\text { Present } \\
I_{u}=1\end{array}$} & \multicolumn{2}{|c|}{$\begin{array}{l}\text { Present } \\
I_{u}=0.1\end{array}$} \\
\hline & & & $\begin{array}{c}\text { Absent } \\
I_{u}=0\end{array}$ & \multicolumn{2}{|c|}{$\begin{array}{l}\text { Absent } \\
I_{u}=0\end{array}$} & \multicolumn{2}{|c|}{$\begin{array}{c}\text { Absent } \\
I_{u}=0\end{array}$} \\
\hline Extension & Extension & rcentage $E_{\%}$ & $\begin{array}{c}\text { Extension } \\
\text { percentage } E_{\%}\end{array}$ & \multicolumn{2}{|c|}{ Extension percentage $E_{\%}$} & \multicolumn{2}{|c|}{ Extension percentage $E \%$} \\
\hline $\begin{array}{l}\text { Exposure } \\
\text { index }\end{array}$ & \multicolumn{7}{|c|}{$\sum\left(\mathrm{I}_{\mathrm{u}} \cdot E_{\%}\right)$} \\
\hline
\end{tabular}

\subsection{Seismic hazard index (ISh)}

The last parameter contributing to the risk index is the seismic hazard $\left(\mathrm{I}_{\mathrm{Sh}}\right)$, related to the specific site where the building — or even portions of it—is located and to the characteristics of the soil, including aspects related to its geological and geotechnical features. The fastest way to determine $I_{S h}$ consists in linking it directly to the seismic hazard, for instance in terms of Peak Ground Acceleration (PGA) on reference rigid soil for a 475-years return period; possible differences can be otherwise present if the considered monumental complex develops over a wide territory. In presence of micro-zonation analyses, the score parameter can be modified by adopting an $I_{s h}$ equal to 0 for the SU characterised by the lowest PGA, and equal to 1 for the SU characterised by the highest PGA. At the same time, interpolation can define intermediate values. If no specific data are available, $I_{S h}$ can be assumed constant for all the SUs, i.e. with unitary value. This approximation is reasonable considering that the variation of the seismic hazard within the site of the monumental complex shall be contained.

\subsection{Seismic risk index (ISU)}

Once evaluated the three scores representing vulnerability, exposure, and seismic hazard, the seismic risk $\left(I_{S U}\right)$ for the analysed SU can be determined. As summarised in Table 5, the scores provided by Sections 2 and 5 of the LEXSIS form are referred to the whole SU, while those referred to Section 3 and 4 are evaluated floor by floor. Therefore, the sum of the three indexes $\left(I_{V}, I_{E}, I_{S h}\right)$ previously evaluated is normalised, avoiding that a unit with a higher number of floors is automatically associated with a higher seismic risk. The sum is thus divided for the floor number $\left(F_{n}\right)$ plus 2, where 2 represents the score sources not related to the floors, i.e. the general vulnerability (Section 2) and the seismic hazard (Section 5). Equation (4) presents the evaluation of $I_{S U}$ :

$$
I_{S U}=\frac{\left(I_{V}+I_{E}+I_{S h}\right)}{F_{n}+2}
$$


Table 5 Partial scores determined by the LEXSIS sections

\begin{tabular}{lll}
\hline LEXSIS form sections & Score evaluation & Score \\
\hline Section 2 & Global, i.e. whole unit & $\mathrm{I}_{\mathrm{V}}$ \\
Section 3 & Floor by floor & \\
Section 4 & Floor by floor & $\mathrm{I}_{\mathrm{E}}$ \\
Section 5 & Global, i.e. whole unit & $\mathrm{I}_{\mathrm{Sh}}$ \\
\hline
\end{tabular}

\section{Application to a case study: the Certosa di Calci complex}

The monastery of the Certosa di Calci develops on a large area in the municipality of Calci (close to Pisa, Italy) in a strategic position in the South-Western foothill of Monte Pisano.

The monumental complex is composed of several portions developed around seven open spaces, including four gardens/courts and three cloisters (Fig. 2). The architectural composition reflects the gradual pursuit of spirituality and connection with God along the West-East axis, highlighted by a natural uphill. The filter among the world chaos and the spirituality of the monastic community is represented by the block known as 'Case basse' currently housing ticket offices, staff offices, museum spaces, private homes and a little church. Developed on two levels for about $140 \mathrm{~m}$, Case Basse limit the main court on the west side; on the north side of the same court is located a two-level block extended toward the garden for $120 \mathrm{~m}$, with a slight change of orientation, housing the Natural History Museum of Pisa University.

By closing the main court on the East side, the central wing of the complex used to house all the functions needed for the monk's life such as the church, the chapter house, the refectory, the kitchens, the guest houses, the cells for the lay brothers, the archives and the food storages. With the church as a central fulcrum, these three-level spaces are developed around two courts on the left of the church and two minor cloisters, the 'Chiostro del capitolo' and the 'Chiostro della foresteria', on its right. Currently, part of this area on the south side is managed by the Superintendence of Cultural Heritage and is devoted to tourist visits; the other part, owned by Pisa University, is used as a museum and employee offices.

In the furthest area from the 'men world' is located the main cloister, surrounded by the monk's cells organised as independent houses, each with its garden.

\subsection{Multidisciplinary knowledge analysis}

\subsubsection{Historical evolution of the monumental complex}

The realisation of the Certosa di Calci began in 1366. Around 1390 the construction of all the essential structures or the monk's life ended: the church, some of the chapels, the refectory, presumably the kitchens, the chapter and part of the cells of the main cloister were built, allowing the settlement of the first family of monks (Piombanti 1884; Giusti and Lazzarini 1993).

The first constructive phase stopped at the end of the century due to the political conflicts between Pisa and Florence: to this period also belongs the realisation of 'Chiostro del capitolo' while, on the other hand, the 'Chiostro della foresteria' is dated later as a consequence of the misalignments between the cloister vaults and the surrounding structures and in relation to hosted functions (Manghi 1911). 


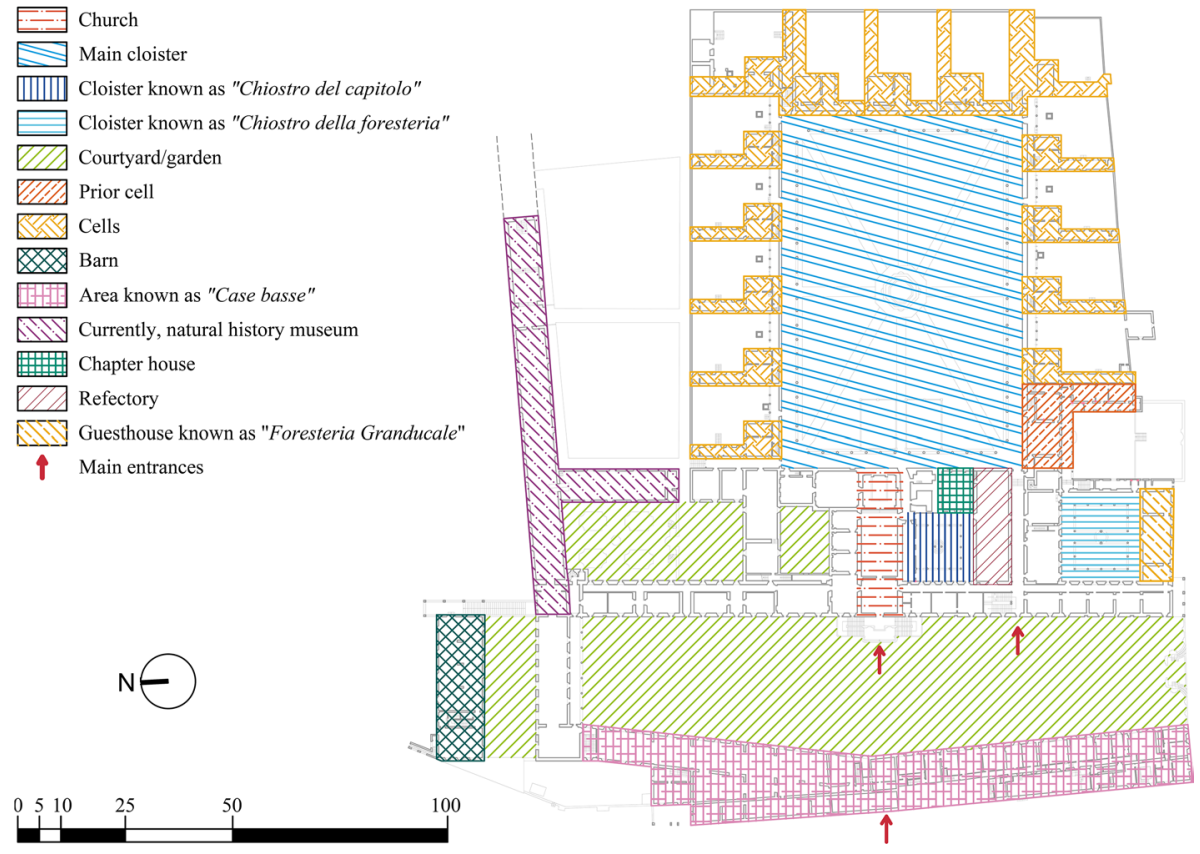

Fig. 2 First plan of the Certosa Monumental complex with the indication of the main spaces

In 1606 relevant renovation works, concentrated in the Southern part of the monastery started, e.g. the superelevation of some blocks, the restoration of the two minor cloisters by adding a system of irregular groin vaults to close the 14th-century open space in the 'Chiostro del capitolo'. The mayor cloister was interested by several modifications between 1618 and 1634, with the raising up of the cells' level due to health reasons, the increased dimensions and the addition of two new cells (Giusti and Lazzarini 1993; Niglio 2005); renovation works also interested the 'Case basse'. The new monumental entrance in front of the church was realised in 1677, together with the chapel of San Sebastiano and the women guest houses (Piombanti 1884; Giusti and Lazzarini 1993).

The last relevant transformation phase started in 1769 with the prior Alfonso Maggi, brought the building to its current appearance (Fig. 3). The main court was doubled by adding new blocks, the church became the central fulcrum, and the symmetry of the complex was finally achieved, introducing the portion missing on the southern corner. The renovation of the refectory, the construction of a new tower bell, the realisation of a new monumental staircase, the decoration of several spaces of the complex and new structures on the northern side were even performed (Piombanti 1884; Manghi 1911).

In 1870 part of the southern area of the complex was granted to the Regio Conservatorio di Sant'Anna and modifications were realised to meet the new needs, such as the creation of internal connections among the cells, later closed (Gioli 2015). During the 1st world war, several non-structural modifications later restored (Gioli 2015) were introduced for military purposes. The last monks definitively left the monastery in 1972; seven years later, the complex was partially donated to Pisa University and used as a museum. The analysis of all these modifications allowed to fully understand the morphological evolution of the complex was almost reconstructed (Fig. 4), a synthesis of achieved results is presented in Fig. 5 for the ground floor level of a representative building portion. 


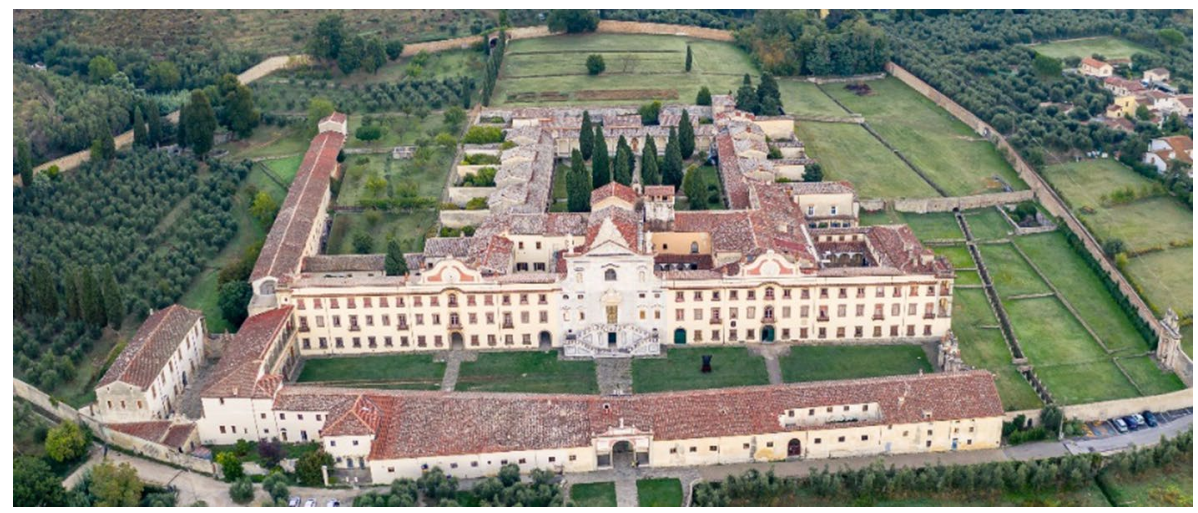

Fig. 3 View of the monumental complex. Photo by courtesy of Guglielmo Giambartolomei

\subsubsection{Structural and geometrical state of the art}

An accurate geometrical survey was performed using direct and indirect measurements, thanks to the cooperation with other research groups of Pisa University. The direct measurements were taken manually through measuring tapes, surveyor's rod and other tools useful to achieve the dimensions of a space or of a structural element. The indirect measurements were performed by using Terrestrial Laser Scanner (TLS), which measures the position of a huge amount of points, finally resulting in the so-called 'point cloud model'. Once elaborated in CAD environment, the point cloud model provided highly accurate plans and sections of the building.

Several investigations were used to collect information about geometrical and structural features. Attention was paid to the typology and dimensions of structural elements, to the consistency of walls, to the typology of floors, to the presence of vulnerabilities or critical issues, the cracking scenario, etc.

In-depth in-situ investigations were mainly concentrated in the area marked in Fig. 6, affected by several maintenance issues causing relevant degradation phenomena and evident vulnerabilities.

Plaster removals on wall and vault lower surfaces to determine the masonry typology and texture were executed, together with endoscopic analyses to assess the thickness and the inner morphology. Direct measurements of floor stratigraphy to estimate the loads acting on bearing elements and assessing the presence of the different layers of filling material were completed.

The in-situ investigations allowed the achievement of a high knowledge level in the marked area in general and, in particular, where higher critical issues or discontinuitiesaccording to the morphological evolution-were supposed to be. The organised investigation plan accounted for the possible presence of frescoes, painting, precious floors, and all the other potential artistic assets to be preserved.

Almost all the investigated walls exhibited a continuous thickness, without cavities or internal nuclei. Seven typologies of masonry patterns were recognised, including also the areas naturally devoid of plaster within the entire complex (Fig. 7a). No clear correspondence between the masonry typology and the constructive phases detected from the historical analysis (Fig. 5) was recognised, as well as the lack of suitable connections among 


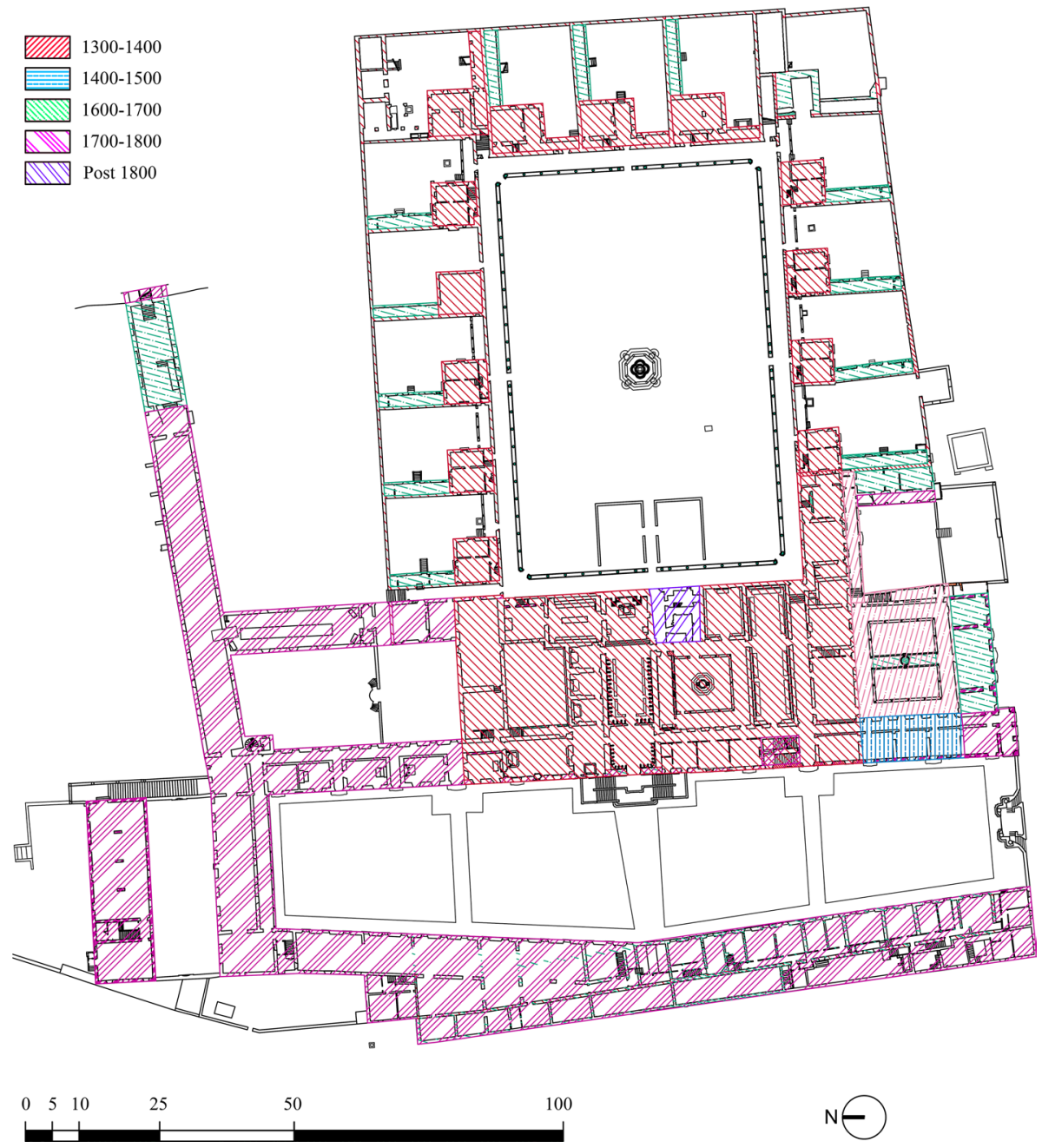

Fig. 4 First plan of the Certosa with the indication of the macro-constructive phases according to the legend

perpendicular walls. No experimental tests for masonry mechanical characterisation were performed: mechanical properties were estimated based on literature and standards' indications (Circolare 21/01/2019), grouping the identified categories basing on similarities.

The survey revealed different typologies of vaults (i.e. barrel, groin, pavilion, dome) with an average height of 5-6 $\mathrm{m}$ on the first and second floors. With inter-floor height in the range of $3 \div 4 \mathrm{~m}$, the third floor was characterised by mainly wooden floor structures with brick elements.

The roof structure was not thoroughly investigated due to accessibility (and safety) reasons; it appeared composed of timber-frame structures or timber-truss elements directly bearing the covering layers. Where possible, a specialised technician assessed the maintenance condition of the timber elements.

The performed investigations also included the cracking scenario survey by recording position and (estimated) entity of the existing cracks to identify structural deficiencies and 

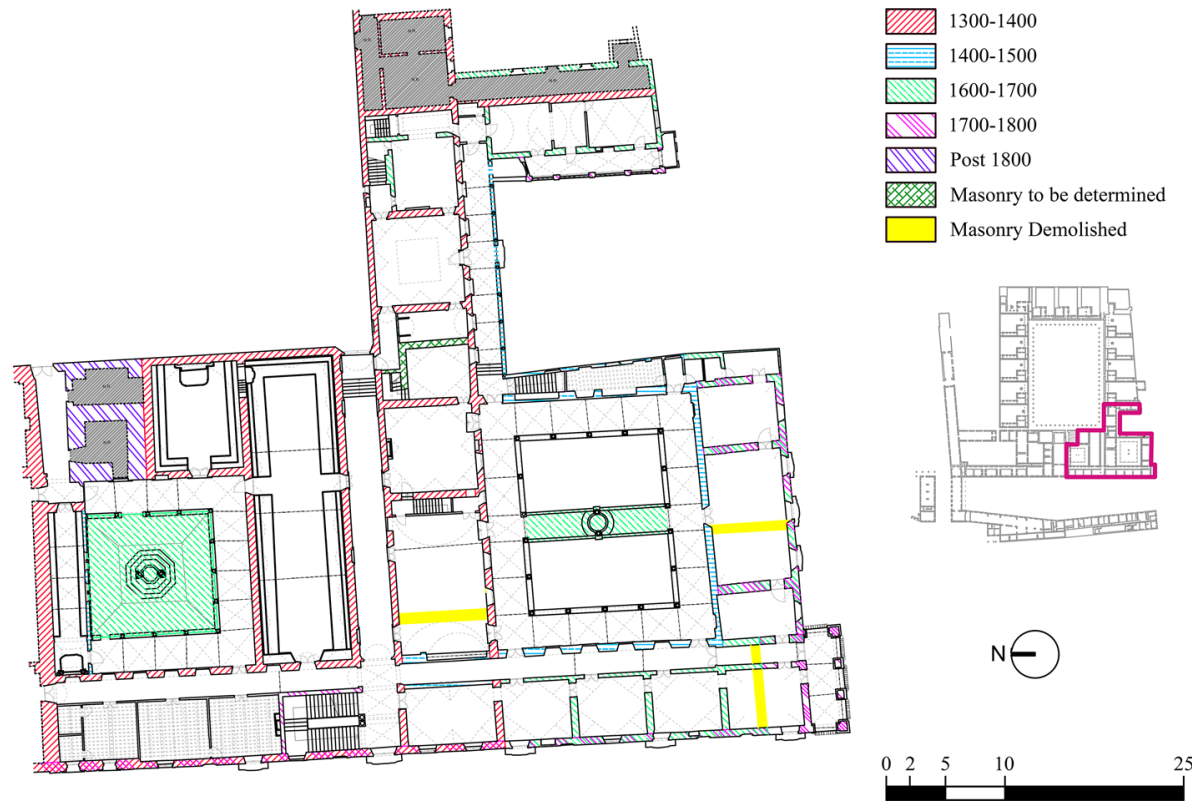

Fig. 5 First plan of a portion of the Certosa with the indication of the macro-constructive phases according to the legend

local mechanisms (Fig. 7b). Finally, the distribution and the state of tension of the steel tie rods were surveyed.

\subsection{Determination and description of the structural units}

Several structural units were identified within the complex starting from the reconstruction of the building's morphological evolution; the critical/historical analysis allowed the subdivision of the whole complex according to the macro-constructive phases. Where clearly recognisable, the typical architectural features were a useful parameter to identify independent SUs such as the Church (SU_1) and the cells in the cloister (SU_3).

The subdivision criteria did not include the masonry typology: despite the different construction periods and the slightly different characteristics (in terms of shape, dimensions and disposition of stones and brick elements), their heterogeneity within the SA did not allow to directly link SUs to this parameter placement. Similar considerations can also be made concerning floors' typology, not highlighting relevant differences within the same horizontal level.

Basing on the above-made considerations, a first subdivision of the Certosa di Calci complex led to the determination of eight different macro Structural Units (SUs) — namely from SU_1 to SU_7, highlighting the progressive morphological evolution of the aggregate (Fig. 8). Two of the original macro-units were joined together (on the base of architectural and structural features) and are presented as SU_6.1 and SU_6.2. For the identification of single monks' cells within SU_3, a letter was used (except for the first two cells on the south wing, included in the SU_2 for proximity reasons). 


\begin{tabular}{|c|c|}
\hline & Barrel vault \\
\hline & Barrel vault with lunettes \\
\hline & Pavilion vault \\
\hline & Pavilion vault with lunettes \\
\hline & Groin vault \\
\hline & Groin vault with lunettes \\
\hline & Mirror vault \\
\hline & Mirror vault with lunettes \\
\hline & Dome vault \\
\hline & Timber floor \\
\hline & Rigid diaphragm \\
\hline & Horizontal storeys with false ceiling \\
\hline & Not visible floor \\
\hline
\end{tabular}

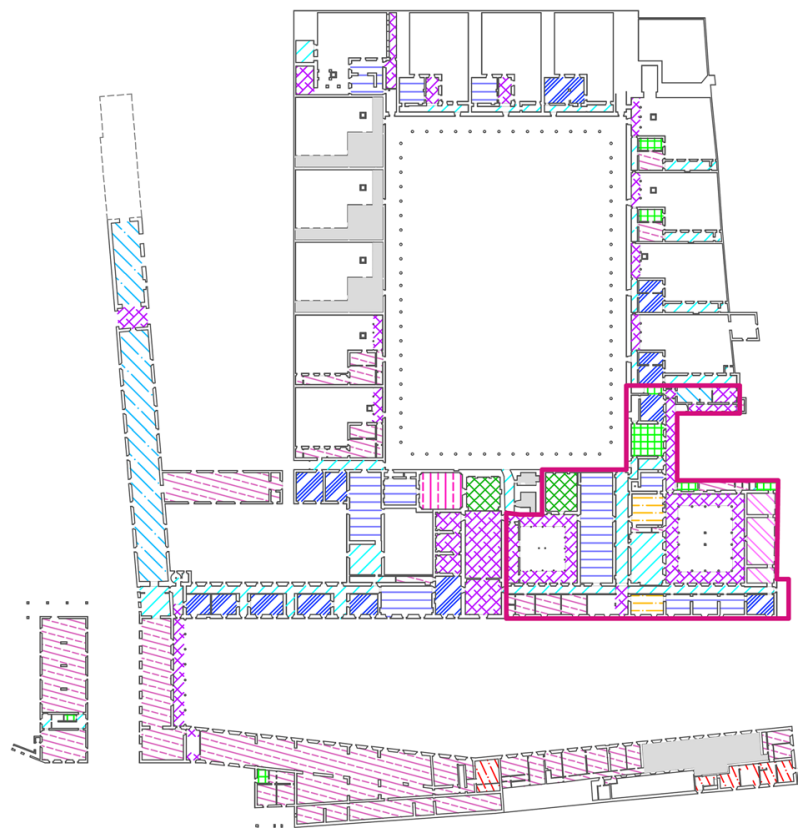

Fig. 6 First plan of the Certosa Monumental complex with the identification of the surveyed floor typology
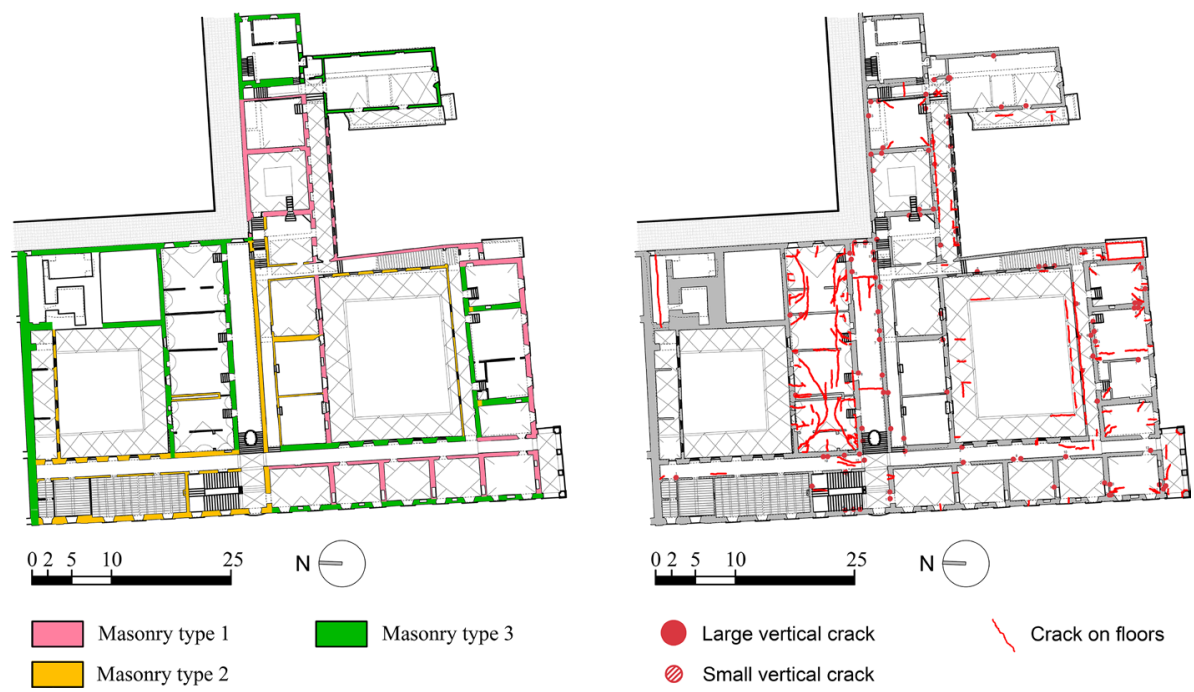

Fig. 7 Second plan of the portion of the monumental complex more in-depth analysed representing: a the survey of the masonry typologies, $\mathbf{b}$ the crack pattern survey

The execution of more in-depth investigations in correspondence of a specific portion of the complex led to a more refined subdivision of $\mathrm{SU}_{-} 2$, where eight different sub-units were determined (namely from SU_2.1 to SU_2.8). 


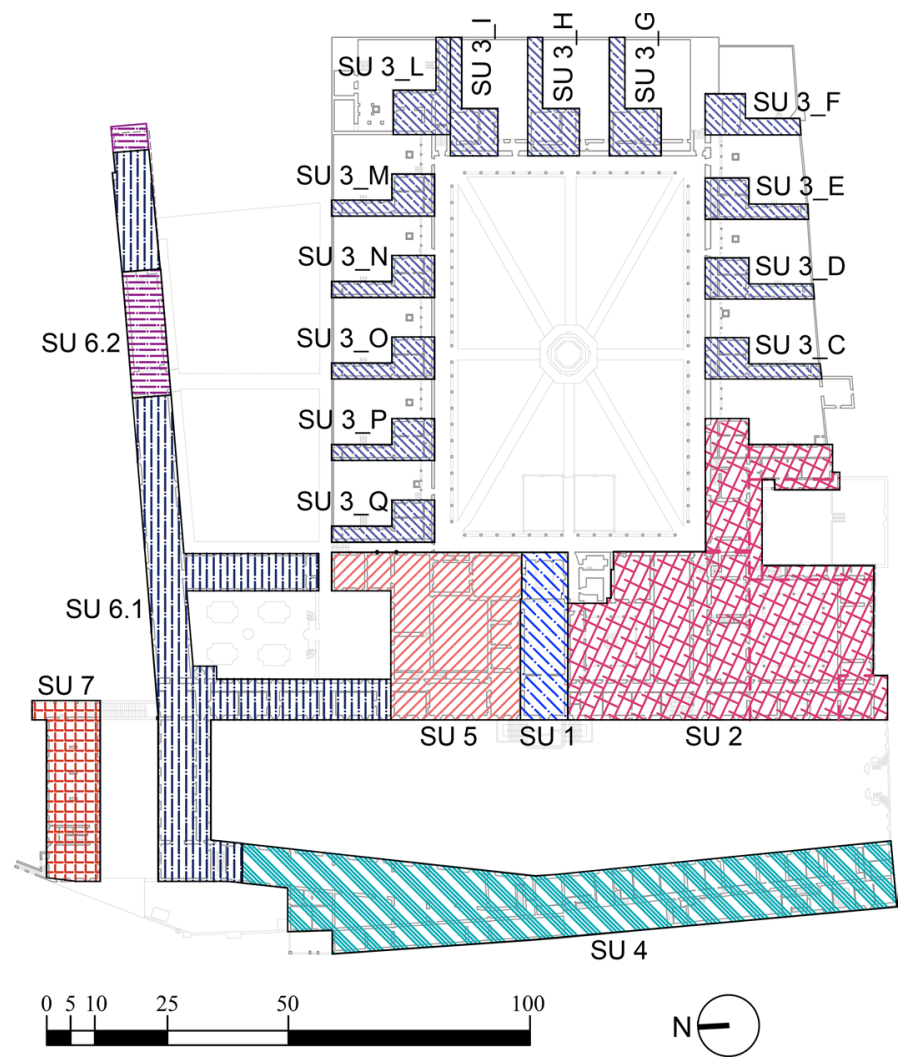

Fig. 8 Identification of the macro-structural units inside the Certosa monumental complex

\subsubsection{Description of the macro-units within the SA}

SU_1 is composed of the church and the spaces below it, born as a warehouse and nowadays hosting part of the temporary museum of the University of Pisa.

SU_2 includes the area on the right of the church, developed around the Chiostro del capitolo. This unit is one of the most heterogeneous of the complex due to the stratifications and transformations that occurred over the centuries.

SU_3 includes the cells of the main cloister. Two connected blocks realised in different periods compose each cell: the original squared block and the rectangular extension, belonging respectively to the fourteenth and seventeenth century. A further subdivision was avoided due to the limited size of the portion.

SU_4 corresponds to the Case Basse portion. Despite the relevant heterogeneity of the ground floor of this area, further subdivisions were avoided due to the few historical information available and to the lack of specific in-situ investigations deepening the knowledge. Besides, the overall homogeneity on the first floor and roof levelwhose renovation and enlargement belongs to the same constructive phase between the eighteenth and nineteenth century-makes it difficult to recognise a reliable inner subdivision. 
Fig. 9 Identification of the subunits within the SU_2 macrostructural unit

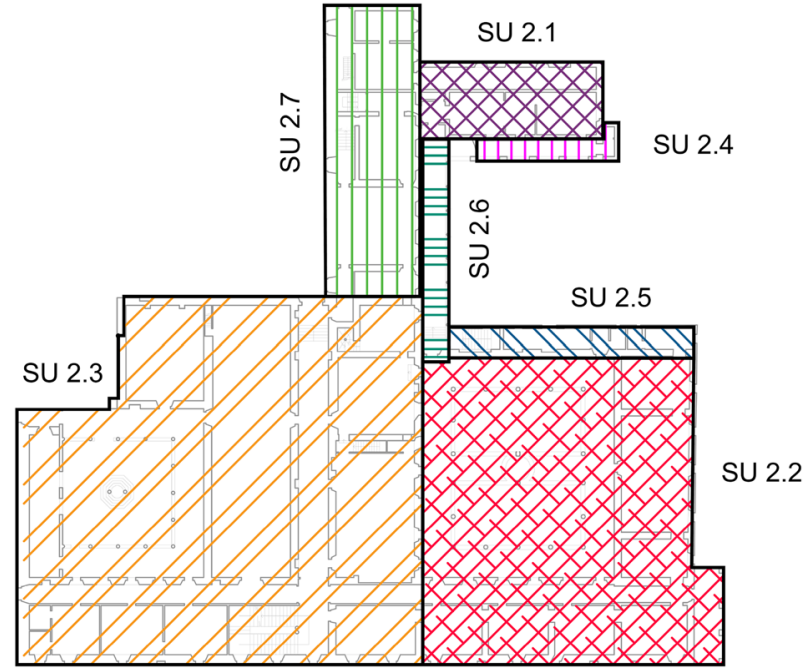

SU_5 includes the blocks on the left of the church organised around the first of the two inner courts. The first two floors date back to the first constructive phase, with several modifications during the years, while the third floor was (probably) realised in the seventeenth century.

SU_6, as said subdivided into two sub-units, houses the Natural History Museum of the Pisa University. SU_6.1 is the northern extension desired by the prior Maggi in the eighteenth century and connects the main court with the block constituting SU_6.2, being otherwise pre-existent.

SU_7 is composed of an isolated block built during the priorate of Maggi to house the barn.

\subsubsection{Description of the sub-units within SU_2}

Thanks to the in-depth investigations performed resulting in a high knowledge level, SU_2 was provided by a more refined subdivision, leading to the determination of seven different structural sub-units, briefly described in the following and represented in Fig. 9.

SU_2.3 represents one of the most ancient parts of the complex, subjected therefore to many modifications over the years. The separation of SU_2.3 from SU_2.2, belonging to a slightly later period, is highlighted by the different vault typologies recognised on the ground floor.

SU_2.7 consists of part of the prior cell and of the adjacent cell, as well as SU_2.1, including the later enlargement of the above-mentioned portions. The distinction between the two units is given, besides the different constructive phases, by the partial wall discontinuity and the presence of totally independent roof structures.

Finally, SU_2.4, SU_2.5 and SU_2.6 are extensions fully separated from the adjacent blocks. SU_2.4 is a two-level portico with a terrace realised between the eighteenth and nineteenth century, concurrently with the realisation of the library on the last floor of the pre-existing SU_2.1. SU_2.6 is, again, composed of a three-level portico, realised in the fifteenth century to decorate the prior cell, whose structure shows a system of pillars 
supporting groin or barrel vaults leaning against the pre-existing Prior cell. The distinction between SU_2.7 and SU_2.6 is highlighted even by the adoption of two independent roof structures.

SU_2.5 is composed of a three-level structure with pillars in correspondence with the ground floor. This construction is not well dated-back in the historical documents available, therefore assuming the first two floors contemporary to the one of SU_2.6. SU_2.5 represents, generally speaking, the connection between the portico of the prior cell (SU_2.6) and the underlying garden.

\subsection{Application of the classification form and results}

The LEXSIS form described in Section 0 was filled in for each unit/sub-unit determined, providing a resulting representative risk index. Among the cells, only the ones identified as SU2_3C and SU2_3G in Fig. 8 were analysed, extending then results to all other cells basing on an overall structural, architectural and geometrical homogeneity.

Due to the considerably different knowledge levels achieved within the complex, two different risk hierarchies were provided. The first one was related to sub-units identified within SU2 (higher knowledge level achieved), and the other covered all the other SU previously defined (lower knowledge level achieved); this allowed a reliable and realistic comparison of the structural performance in terms of resulting $I_{S U}$ among units characterised by almost the same knowledge level.

Generally, the same $\mathrm{I}_{\mathrm{Sh}}$ equal to 1 was assumed for all the units and sub-units, as shown in Tables 6 and 7. The mentioned score will be updated in the future if performing a seismic microzonation will provide different results for the areas occupied by the SUs. Anyway, a very small variation is reasonably expected since dealing with a building site and not with a wide territory.

Table 6 summarises the results achieved for the macro-seismic classification of SU_2; for each sub-unit, the score provided by each form section is presented, highlighting the primary structural deficiencies-related to the different aspects of vulnerability, exposure, seismic hazard, regularity, etc. The position of each SU within the macro-seismic rank is finally determined by the $I_{S U}$ score (whose normalised values are evaluated according to Eq. (4). In this way, the areas where interventions (or more indepth investigations) are needed are easily identified.

The most vulnerable sub-units within SU_2 are SU_2.3 and SU_2.2, provided by a very similar score (2.95 and 2.89 in the case of normalised values). As highlighted by the structural and geometrical surveys, SU_2.3 was characterised by relevant structural complexity, reflected in low regularity in plan and elevation and in the wide presence of walls without vertical continuity. Besides, some particularly vulnerable areas are present, for instance, in correspondence of the vault above the refectory and some shored-up floors at the third level. Instead, the score of SU_2.2 was mainly influenced by material degradation and a relevant cracking pattern-i.e. a widespread presence of cracks of large size whose position and distribution within the unit suggests possible local mechanisms' activation.

The third position is owned by SU_2.5 due to the in-plan irregularity and presence of a widespread crack scenario affecting structures and of shored-up floors.

The fourth position is owned SU_2.7, presenting a quite irregular plan's organisation and large openings alternate to rather small walls, leading to the generation of shored up floors in correspondence of the last level. 
Table 6 Risk scores obtained for the subunits of the SU_2

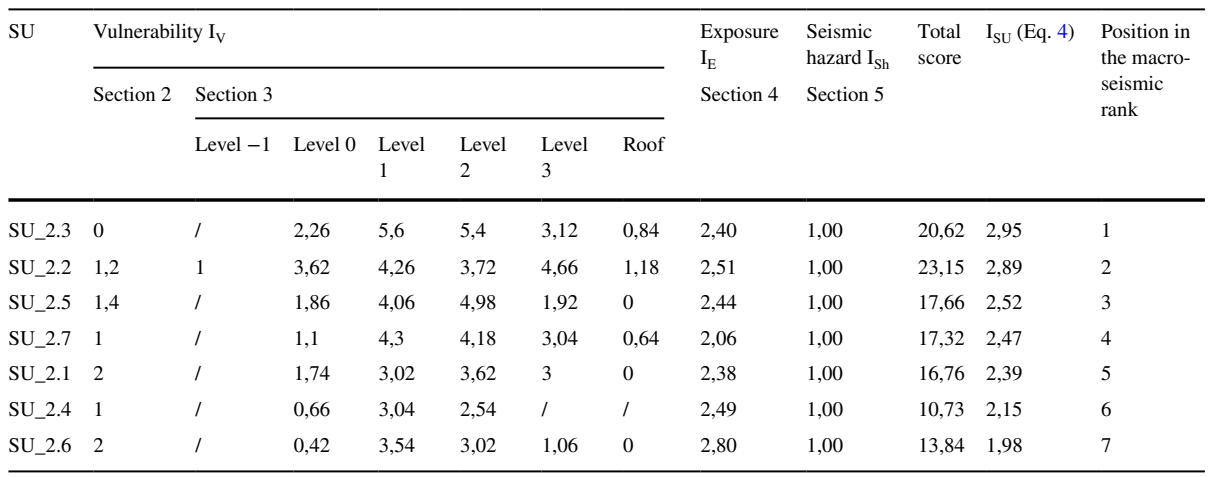

When a floor level is absent, the symbol / is used to identify its missing score

The SU_2.4 does not have any data concerning the roof, being the last level a terrace

Finally, SU_2.1, SU_2.4 and SU_2.6 occupy the last positions in the risk ranking because of their regularity and the minor critical issues surveyed; results achieved are almost comparable $(2.39,2.15$ and 1.98 , respectively). Figure 10 graphically represents the results obtained for the sub-units of SU_2, while Table 7 summarises, as an example, the scores achieved for the different sections, according to the form organisation for SU_2.3. In Table 7, the subdivision of the data contained in Section 3 reflects the scheme represented in Fig. 11. A more detailed table representing the scores assigned to SU_2.3 is provided as an attachment to the present paper.

Table 8 summarises the values of the seismic risk indexes for the rest of the monumental complex; Fig. 12 provides the graphical representation of the results.

The most vulnerable (macro) units are the SU_5 and SU_4, characterised by an almost identical score (normalised values equal to 2.67 and 2.58 , respectively). Both of them present a high structural complexity due to the several phases characterising their morphological evolution. Further, SU_5 has a remarkable crack pattern at the last level, and SU_4 has a very irregular and elongated shape, and some shored up floors.

In the third position, there is SU_6.1, characterised by structural complexity and remarkable crack pattern at the last level.

SU_3G and SU_3C occupy the two following positions with a similar score due to the very similar structure, mainly influenced by some local mechanisms.

SU_1 is in the sixth position, while SU_6.2 and SU_7 are at the bottom of the macroseismic rank thanks to their simple and regular shape and to the absence of relevant critical issues.

\section{Conclusions}

The present paper shows a methodology for the macro-seismic risk classification of monumental historical buildings, practically applied to the case study of the Certosa di Calci complex, close to Pisa (Italy). The method is organised in four main steps, including 
Table 7 Summary of the scores achieved in the different form section of the unit SU_2.3

\begin{tabular}{|c|c|c|c|c|c|c|c|c|c|c|}
\hline \multirow{3}{*}{$\begin{array}{c}\text { Section } 2- \\
\text { SU general } \\
\text { vulnerability }\end{array}$} & \multicolumn{5}{|l|}{ Regularity } & \multicolumn{5}{|c|}{ Total score 1.1} \\
\hline & Compact shape & \multicolumn{3}{|c|}{\begin{tabular}{|c|}
$\begin{array}{c}\text { Ratio among the side } \\
\text { of the circumscribing } \\
\text { rectangle }\end{array}$ \\
\end{tabular}} & \multicolumn{2}{|c|}{ Recesses or ledges } & \multicolumn{2}{|c|}{$\begin{array}{c}\text { Presence of } \\
\text { vulnerable elements }\end{array}$} & \multicolumn{2}{|c|}{$\begin{array}{c}\text { Variation of mass and } \\
\text { stiffness }\end{array}$} \\
\hline & 0 & \multicolumn{2}{|r|}{0} & \multicolumn{3}{|c|}{0} & \multicolumn{2}{|c|}{0} & \multicolumn{2}{|l|}{0} \\
\hline \multirow{6}{*}{$\begin{array}{c}\text { Section } 3.1- \\
\text { Vertical } \\
\text { structures } \\
\text { vulnerability }\end{array}$} & \multicolumn{3}{|c|}{ Section 3.10 - SU level 0} & \multicolumn{4}{|c|}{ Section 3.11 - SU level 1} & \multicolumn{3}{|c|}{ Section 3.12 - SU level 2} \\
\hline & \multicolumn{2}{|l|}{ Total score } & 2.08 & \multicolumn{3}{|c|}{ Total score } & 3.8 & \multicolumn{2}{|r|}{ Total score } & 2.64 \\
\hline & \multicolumn{2}{|c|}{ Masonry typology } & 1.00 & \multicolumn{3}{|c|}{ Masonry typology } & 1.60 & \multicolumn{2}{|c|}{ Masonry typology } & 0.80 \\
\hline & \multicolumn{2}{|l|}{ Vulnerability } & 0.78 & \multicolumn{3}{|c|}{ Vulnerability } & 1.90 & \multicolumn{2}{|r|}{ Vulnerability } & 1.54 \\
\hline & \multicolumn{2}{|c|}{ Local collapse mechanisms } & 0 & \multicolumn{3}{|c|}{ Local collapse mechanisms } & 0 & \multicolumn{2}{|c|}{ Local collapse mechanisms } & 0 \\
\hline & \multicolumn{2}{|c|}{ Retrofit intervention } & 0 & \multicolumn{3}{|c|}{ Retrofit intervention } & 0 & \multicolumn{2}{|c|}{ Retrofit intervention } & 0 \\
\hline & Section $3.20-S U$ le & evel 1 & Section & $3.21-\mathrm{SU}$ le & vel 2 & Section 3. & $3.22-\mathrm{SU}$ le & evel 3 & Section $3.24-\mathrm{SU}$ & roof \\
\hline & Total score & 1.68 & Tota & al score & 3.0 & Total & I score & 3.14 & Total score & 0.86 \\
\hline & Floor typology & 0 & Floor & typology & 0 & Floor ty & ypology & 0 & Floor typology & 0 \\
\hline Section $3.2-$ & Floor characteristics & 1.00 & Floor che & aracteristics & 1.80 & Floor char & racteristics & 3.00 & Floor characteristics & 1.00 \\
\hline structures & Vulnerabilities & 0.62 & Vulne & erabilities & 0.78 & Vulnera & abilities & 1.02 & Vulnerabilities & 0.14 \\
\hline & Retrofit techniques & -0.20 & Retrofit & techniques & 0 & Retrofit te & techniques & -0.9 & Retrofit techniques & -0.3 \\
\hline & & & & & & & & & $\begin{array}{c}\text { Roof causing } \\
\text { horizontal thrusts }\end{array}$ & 0 \\
\hline & $\begin{array}{c}\% \text { visible floor ( } W \\
\text { parameter) }\end{array}$ & 1.00 & $\begin{array}{r}\% \text { visibl } \\
\text { para } \\
\end{array}$ & $\begin{array}{l}\text { le floor ( } W \\
\text { ameter) }\end{array}$ & 1.00 & $\begin{array}{r}\% \text { visible } \\
\text { param }\end{array}$ & $\begin{array}{l}\text { e floor ( } W \\
\text { meter) }\end{array}$ & 1.00 & $\begin{array}{c}\% \text { visible floor ( } W \\
\text { parameter) }\end{array}$ & 1.00 \\
\hline Section 3.3 - & Section $3.30-$ SU lev & vel 0 & & & & & & otal sco & ore 0.48 & \\
\hline Non-struct. & Section 3.31-SU lev & vel 1 & & & & & & otal sco & ore 0.48 & \\
\hline elements & Section $3.32-$ SU lev & vel 2 & & & & & & otal sco & ore 0.24 & \\
\hline & Section 4.1 - Exposu & Ire leve & & & & & & 0.8 & & \\
\hline & Section 4.2 - Exposu & Ire leve & & & & & & 0.9 & & \\
\hline Section 4 - & Section 4.3 - Exposu & Ire leve & & & & & & 0.3 & & \\
\hline & Section 4.4 - Exposu & Ire leve & & & & & & 0.1 & & \\
\hline & Section 4.5 - Exposu & Ire roo & & & & & & 0.1 & & \\
\hline $\begin{array}{l}\text { Section 5- } \\
\text { seismic } \\
\text { hazard }\end{array}$ & & eismic & hazard & & & & & 1.0 & & \\
\hline & Isu for $\mathrm{S}$ & U_ 2.3 & & & & & & 20.6 & & \\
\hline
\end{tabular}

historical knowledge, structural surveys, determination of relevant units and finally aiming to identify the most vulnerable areas within the structural aggregate. LEXSIS form for the classification of main parameters characterising single structural units is proposed. This form represents a useful survey tool and a way to summarise all the relevant building characteristics, besides providing a seismic risk index. The proposed procedure originates accounting for what actually presented in the current scientific literature concerning existing constructions' survey in the post-seismic phase, with the aim of detecting damages and evaluating how to behave for the retrofit/reconstruction phase. Of course, differences are present, first of all, being the presented method proposed for monumental buildings intended as structural aggregates, while, in the majority of cases, existing methods are related to ordinary constructions. Of fundamental importance is therefore the identification of the structural units within the complex, which, as clearly stated, can be performed 


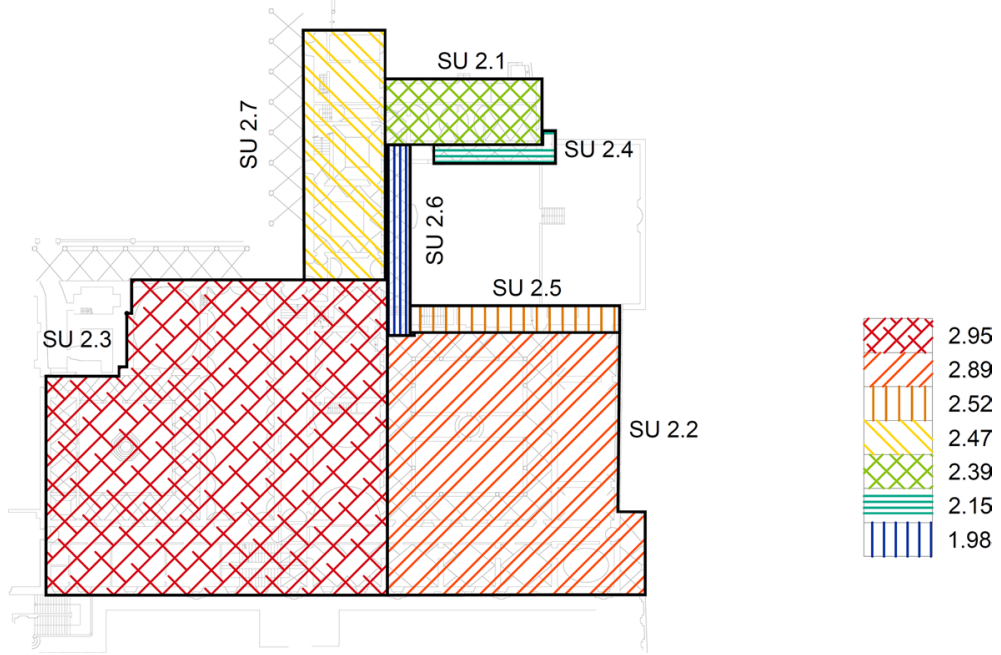

Fig. 10 Graphic representation of the results achieved for the SU_2 and its subunits

Fig. 11 Identification of the levels for the evaluation of the parameters with reference to a building section

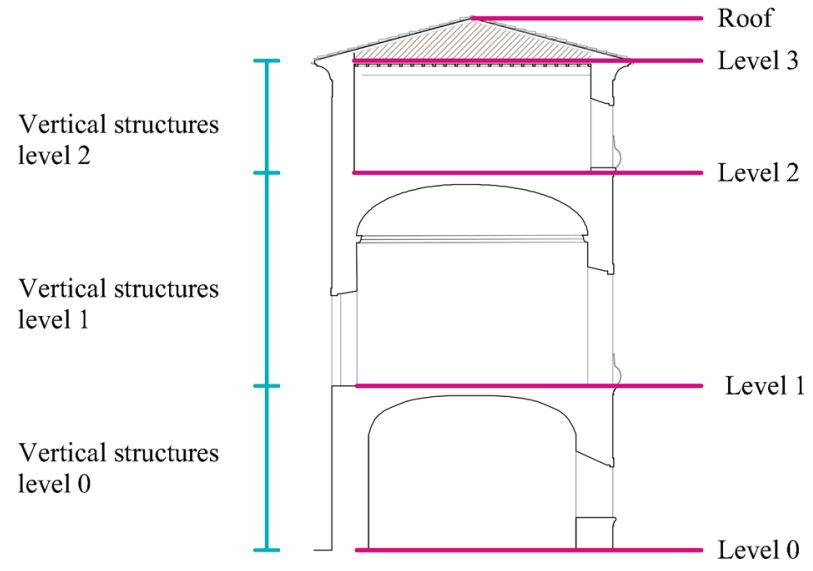

only through the different steps of analysis of the morphological evolution, structural and material survey and so on. Besides, for structural aggregates to have several superpositions, modifications and changes that, together with the differences frequently dependant on the functional destinations foreseen for the different levels, make relevant the discrepancies among following storeys. The proposed approach, differently from existing ones, accounts for this, allowing to determine and highlight differences that otherwise would be neglected.

A 'risk priority list', depending on the value of the seismic risk index achieved for each SU, can be finally draft. This list will be useful for public administrations and buildings' 
Table 8 Risk scores obtained for the complex unit except for SU_2

\begin{tabular}{|c|c|c|c|c|c|c|c|c|c|c|c|c|}
\hline \multirow[t]{3}{*}{ SU } & \multicolumn{7}{|c|}{ Vulnerability $I_{V}$} & \multirow{3}{*}{$\begin{array}{l}\text { Expo- } \\
\text { sure } I_{E} \\
\text { Sec- } \\
\text { tion } 4\end{array}$} & \multirow{3}{*}{$\begin{array}{l}\text { Seismic hazard } \\
\mathrm{I}_{\text {Sh }} \\
\text { Section } 5\end{array}$} & \multirow{3}{*}{$\begin{array}{l}\text { Total } \\
\text { score }\end{array}$} & \multirow{3}{*}{$\begin{array}{l}\mathrm{I}_{\mathrm{SU}} \\
\text { (Eq. 4) }\end{array}$} & \multirow{3}{*}{$\begin{array}{l}\text { Position in } \\
\text { the macro- } \\
\text { seismic rank }\end{array}$} \\
\hline & \multirow{2}{*}{$\begin{array}{l}\text { Sec- } \\
\text { tion } 2\end{array}$} & \multicolumn{6}{|c|}{ Section 3} & & & & & \\
\hline & & $\begin{array}{l}\text { Level } \\
-1\end{array}$ & $\begin{array}{l}\text { Level } \\
0\end{array}$ & $\begin{array}{l}\text { Level } \\
1\end{array}$ & $\begin{array}{l}\text { Level } \\
2\end{array}$ & $\begin{array}{l}\text { Level } \\
3\end{array}$ & Roof & & & & & \\
\hline SU_4 & 2,4 & I & 2,38 & 2,8 & 2,96 & 3,22 & 0,62 & 2,67 & 1,00 & 18,05 & 2,58 & 2 \\
\hline SU_6.1 & 2,8 & I & 1,16 & 1,62 & 1,46 & 2,18 & 2,02 & 2,70 & 1,00 & 14,94 & 2,13 & 3 \\
\hline SU_3G & 1,4 & I & 1,38 & 2,44 & 0,147 & I & 2,6 & 0,40 & 1,00 & 9,37 & 1,56 & 4 \\
\hline SU_3C & 1,6 & I & 1,62 & 1,48 & 1,12 & I & 1,56 & 0,40 & 1,00 & 8,78 & 1,46 & 5 \\
\hline
\end{tabular}

When a floor level is absent, the symbol/is used to identify its missing score

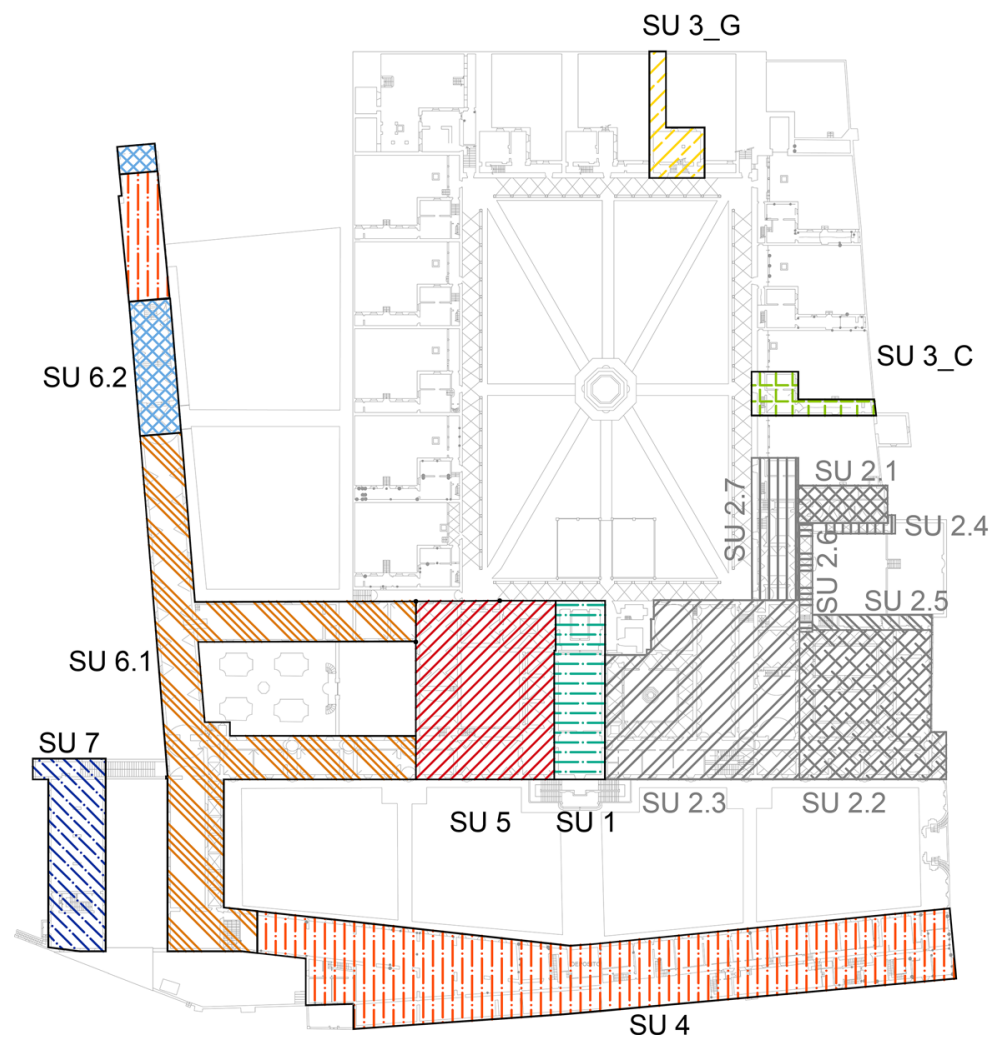

Fig. 12 Graphic representation of the results achieved for the complex, excluding SU_2 
owners in general to promote further investigations - where needed about observed criticisms and problems - and to organise retrofit and mitigation operations, with different priority levels as a consequence of the issues revealed. Knowledge analysis is necessary to collect data concerning the morphological evolution of the aggregate, the structural and geometrical features, and the aspects concerning materials, crack patterns and possible local mechanisms. Of course, a different in-depth level of in-situ investigations leads to different knowledge levels and slightly different approach for the following organisation of retrofit intervention. Thanks to the knowledge acquired, a subdivision of the monumental complex in structural units is proposed. Several parameters such as the constructive phases, the structural typologies, the wall and floor alignment and the material distribution could be accounted to identify, within the aggregate, areas characterised by overall homogeneity. For each SUs, a pre-defined form including vulnerability, exposure and seismic hazard aspects is filled, finally allowing to determine those areas requiring most urgent safety measures.

Supplementary Information The online version contains supplementary material available at https://doi. org/10.1007/s10518-021-01209-7.

Acknowledgements The authors are thankful to the Pisa University and to the Superintendence BAPSAE of Pisa and Livorno for supporting and encouraging this research. The authors would like to thank all the research teams who have collaborated in the framework of the project "Studi conoscitivi e ricerche per la conservazione e la valorizzazione del Complesso della Certosa di Calci e dei suoi Poli Museali" promoted by the Pisa University. In particular, the authors' gratitude goes to Prof. M.G. Bevilacqua and his research team for the execution of the Laser Scanner survey, Prof. A. De Falco and her co-workers for the elaboration of the point clouds in $\mathrm{CAD}$ environment, for the experimental tests performed on chains and for the collaboration during the in- situ investigations. A special thank is also given to the expert technicians of the Laboratorio Ufficiale per le Esperienze sui Materiali da Costruzione of Pisa University for the execution of experimental investigations. Finally, the authors' gratitude goes to Guglielmo Giambartolomei for providing the aerial photo of the Certosa di Calci.

Authors' contribution All authors contributed to the elaboration of the presented research.

Funding Open access funding provided by Università di Pisa within the CRUI-CARE Agreement. Partial financial support was received by the Pisa University in the framework of the project "Studi conoscitivi e ricerche per la conservazione e la valorizzazione del Complesso della Certosa di Calci e dei suoi Poli Museali".

\section{Declarations}

Conflict of interest The authors have no conflicts of interest to declare that are relevant to the content of this article.

Open Access This article is licensed under a Creative Commons Attribution 4.0 International License, which permits use, sharing, adaptation, distribution and reproduction in any medium or format, as long as you give appropriate credit to the original author(s) and the source, provide a link to the Creative Commons licence, and indicate if changes were made. The images or other third party material in this article are included in the article's Creative Commons licence, unless indicated otherwise in a credit line to the material. If material is not included in the article's Creative Commons licence and your intended use is not permitted by statutory regulation or exceeds the permitted use, you will need to obtain permission directly from the copyright holder. To view a copy of this licence, visit http://creativecommons.org/licenses/by/4.0/.

\section{References}

Barbat AH, Moya FYP, Canas JA (1996) Damage scenarios simulation for seismic risk assessment in urban zones. Earthq Spectra 12:371-394. https://doi.org/10.1193/1.1585889 
Benedetti D, Benzoni G, Parisi MA (1986) Seismic vulnerability and risk evaluation for old urban nuclei. Earthq Eng Struct Dynam 16:183-201. https://doi.org/10.1002/eqe.4290160203

Bernardini A (ed) (2000) La vulnerabilità degli edifici: valutazione a scala nazionale della vulnerabilità sismica degli edifici ordinari. CNR-Gruppo Nazionale per la Difesa dai Terremoti CNR-Gruppo Nazionale per la Difesa dai Terremoti Roma, Italy

Bernardini A, Giovinazzi S, Lagomarsino S, Parodi S (2007) The vulnerability assessment of current buildings by a macroseismic approach derived from the EMS-98 scale

Bernardini A, Lagomarsino S (2008) The seismic vulnerability of architectural heritage. Struct Build 4:171-181

Binda L, Cardani G, A S, Valluzzi M, Munari M, Modena C, (2007) Multilevel approach to the vulnerability analysis of historic buildings in seismic areas part 1: detection of parameters for vulnerability analysis through on site and laboratory investigations. Restor Build Monum. https://doi.org/10.1515/ rbm-2007-6171

Borri A, Sisti R; Prota A, Di Ludovico M, Costantini S, Barluzzi M, De Maria A, Aisa E, Bragett A, Savi F, Fagotti G, Baldi L (2017). Analisi del danno degli edifici ordinari nel centro storico di Norcia a seguito del sisma del 2016. In Proceedings of the 17th Anidis International Congress, Pistoia, Italy (pp. 17-21).

Bosiljkov V, D'Ayala D, Novelli VI (2015) Evaluation of uncertainties in determining the seismic vulnerability of historic masonry buildings in Slovenia: use of macro-element and structural element modelling. Bull Earthq Eng 13(1):311-329

Braga F, Dolce M, Liberatore D (1982) A statistical study on damaged buildings and an ensuing review of the M.S.K.-76 scale. In: proceedings of the 7th European conference on earthquake engineeering, Atene

Braga F, Morelli F, Picchi C, Salvatore W (2017) Development of a macroseismic model for the seismic risk classification of existing buildings. In: ANIDIS 2017 L'Ingegneria Sismica in Italia, 2017. Pisa University Press, pp 1-9

Caprili S, Puncello I (2019) Knowledge-based approach for the structural assessment of monumental buildings: application to case studies. Front Built Environ 5:52

Caprili S et al (2017) A knowledge-based approach for the structural assessment of cultural heritage, a case study: La Sapienza Palace in Pisa. Bull Earthq Eng 15:4851-4886. https://doi.org/10.1007/ s10518-017-0158-y

Carocci CF (2012) Small centres damaged by 2009 L'Aquila earthquake: on site analyses of historical masonry aggregates. Bull Earthq Eng 10:45-71

Carreño M-L, Cardona OD, Barbat AH (2007) Urban seismic risk evaluation: a holistic approach. Nat Hazards 40:137-172

Castori G, Borri A, De Maria A, Corradi M, Sisti R (2017) Seismic vulnerability assessment of a monumental masonry building. Eng Struct 136:454-465

CdM (2011) Linee guida per la valutazione e la riduzione del rischio sismico del patrimonio culturale con riferimento alle Norme Tecniche per le costruzioni di cui al decreto del Ministero delle Infrastrutture e dei trasporti del 14 gennaio 2008. Istituto Poligrafico e Zecca dello Stato, Rome, Italy

Chaulagain H, Rodrigues H, Silva V et al (2015) Seismic risk assessment and hazard mapping in Nepal. Nat Hazards 78:583-602

Chinni C, Mazzotti C, Savoia M (2013) RE.SIS.TO®: una metodologia speditiva per la valutazione di vulnerabilità sismica di edifici in muratura e calcestruzzo armato. Paper presented at the XV Convegno ANIDIS - L'Ingegneria Sismica in Italia

Circolare (2019) Istruzioni per l'applicazione dell'Aggiornamento delle Norme tecniche per le costruzioni di cui al decreto ministeriale 17 gennaio 2018

Clementi F, Gazzani V, Poiani M, Lenci S (2016) Assessment of seismic behaviour of heritage masonry buildings using numerical modelling. J Build Eng 8:29-47. https://doi.org/10.1016/j.jobe.2016.09.005

D'Amato M, Laterza M, Diaz D (2018) Simplified seismic analyses of ancient churches in Matera's landscape. Int J Archit Herit 14(1):119-138

D’Ayala D, Speranza E (2002) An integrated procedure for the assessment of seismic vulnerability of historic buildings. Paper presented at the 12th European Conference on Earthquake Engineering

Degli Abbati S, D’Altri A, Ottonelli D, Castellazzi G, Cattari S, Miranda S, Lagomarsino S (2018) Seismic assessment of interacting structural units in complex historic masonry constructions by nonlinear static analyses. Comput Struct 213:51-71

Dogangun A, Sezen H (2012) Seismic vulnerability and preservation of historical masonry monumental structures. Earthq Struct 3:83-95

Dolce M, Moroni C (2005) La valutazione della Vulnerabilità e del Rischio Sismico degli Edifici Pubblici mediante le procedure VC e VM vol 4 
Dolce M, Sabetta F, Colozza R (1996) Seismic risk assessment in the historical centre of Rome. Paper presented at the 11th world conference on earthquake engineering Acapulco, Mexico, 1996

Eleftheriadou AK, Baltzopoulou AD, Karabinis AI (2014) Seismic risk assessment of buildings in the extended urban region of athens and comparison with the repair cost. Open J Earthq Res 3:115-134

EN1991-1-1: Eurocode 1: Action on structures - Part 1-1: General actions- densities, self-weight, imposed loads for buildings. 2004

Ferreira TM, Maio R, Vicente R (2017) Seismic vulnerability assessment of the old city centre of Horta, Azores: calibration and application of a seismic vulnerability index method. Bull Earthq Eng 15:2879-2899. https://doi.org/10.1007/s10518-016-0071-9

Formisano A, Mazzolani F, Florio G, Landolfo R (2010) A quick methodology for seismic vulnerability assessment of historical masonry aggregates. In: Proc. of the COST Action C26 Final Conference "Urban Habitat Constructions under Catastrophic Events, 2010 . pp 577-582

Fuentes DD, Baquedano Julià PA, D’Amato M, Laterza M (2019) Preliminary seismic damage assessment of mexican churches after september 2017 earthquakes. Int J Archit Herit Publ Line. https:// doi.org/10.1080/15583058.2019.1628323

Gioli A (2015) La Certosa di Calci nella Grande Guerra. Riuso e tutela tra Pisa e l'Italia. Edifir, Firenze

Giovinazzi S (2005) The vulnerability assessment and the damage scenario in seismic risk analysis. PhD Thesis, TU Braunschweig

Giovinazzi S, Lagomarsino S (2004) A macroseismic method for the vulnerability assessment of buildings. In: 13th World Conference on Earthquake Engineering, pp 1-6

Giusti MA, Lazzarini MT (1993) La Certosa di Pisa a Calci. Pacini, Pisa

GNDT-SSN (1994) Scheda di esposizione e vulnerabilità e di rilevamento danni di primo livello e secondo livello (muratura e cemento armato)

Grünthal G (1998) European macroseismic scale 1998. European Seismological Commission (ESC)

Guagenti E, Molina C, Mulas G (1988) Seismic risk analysis with predictable models. Earthq Eng Struct Dyn 16:343-359

Jalayer F, Ebrahimian H (2017) Seismic risk assessment considering cumulative damage due to aftershocks. Earthq Engng Struct Dyn 46:369-389

Kalman Šipoš T, Hadzima-Nyarko M (2017) Rapid seismic risk assessment. Int J Disaster Risk Reduct 24:363-380

Kržan M, Gostič S, Cattari S, Bosiljkov V (2015) Acquiring reference parameters of masonry for the structural performance analysis of historical buildings. Bull Earthq Eng 13:203-236. https://doi. org/10.1007/s 10518-014-9686-x

Lagomarsino S (2006) On the vulnerability assessment of monumental buildings. Bull Earthq Eng 4:445-463. https://doi.org/10.1007/s10518-006-9025-y

Lagomarsino S, Giovinazzi S (2006) Macroseismic and mechanical models for the vulnerability and damage assessment of current buildings. Bull Earthq Eng 4:415-443

Lagomarsino S, Cattari S, Degli Abbati S, Ottonelli D (2014) Seismic assessment of complex monumental buildings in aggregate: the case study of Palazzo del Podestà in Mantua (Italy). In: SAHC2014 - 9th international conference on structural analysis of historical constructions, Mexico City, Mexico. pp 14-17

Lantada N, Irizarry J, Barbat AH, Goula X, Roca A, Susagna T, Pujades LG (2010) Seismic hazard and risk scenarios for Barcelona, Spain, using the Risk-UE vulnerability index method. Bull Earthq Eng 8:201-229. https://doi.org/10.1007/s10518-009-9148-z

Lourenço PB, Roque JA (2006) Simplified indexes for the seismic vulnerability of ancient masonry buildings. Struct Masonry Earthq 20:200-208

Lourenço PB, Oliveira DV, Leite JC, Ingham J, Modena C, Da Porto F (2013) Simplified indexes for the seismic assessment of masonry buildings: International database and validation. Eng Fail Anal 34:585-605

Manghi A (1911) La Certosa di Pisa. Mariotti, Pisa

Munari M, Valluzzi M, Cardani G, Anzani A, Binda L, Modena C (2010) Seismic vulnerability analyses of masonry aggregate buildings in the historical centre of Sulmona (Italy)

Neves F, Costa A, Vicente R, Oliveira CS, Varum H (2012) Seismic vulnerability assessment and characterisation of the buildings on Faial Island, Azores. Bull Earthq Eng 10:27-44. https://doi.org/10. 1007/s10518-011-9276-0

Niglio O (2005) Il chiostro grande della Certosa di Calci: storia, paesaggio, architettura. In: Benassi L (ed). Primula, Ghezzano (Pisa)

Novelli VI, D'Ayala D (2015) Log-ideah: Logic trees for identification of damage due to earthquakes for architectural heritage. Bull Earthq Eng 13(1):153-176. https://doi.org/10.1007/s10518-014-9622-0 
Novelli VI, D'Ayala D (2019) Use of the knowledge-based system LOG-IDEAH to assess failure modes of masonry buildings, damaged by L'Aquila earthquake in 2009. Front Built Environ 5:95

Orlando M, Betti M, Spinelli P (2019) Assessment of structural behaviour and seismic retrofitting for an Italian monumental masonry building. J Build Eng 29:101115. https://doi.org/10.1016/j.jobe.2019. 101115

Pasquale GD, Orsini G, Romeo RW (2005) New developments in seismic risk assessment in Italy. Bull Earthq Eng 3:101-128. https://doi.org/10.1007/s10518-005-0202-1

Di Pasquale G, Orsini G (1997) Proposta per la valutazione di scenari di danno conseguenti ad un evento sismico a partire dai dati ISTAT Atti dell 8:477-486

Piombanti G (1884) La Certosa di Pisa e dell'isola di Gorgona. Fabbreschi, Pisa

Quagliarini E, Lucesoli M, Bernardini G (2019) Rapid tools for assessing building heritage's seismic vulnerability: a preliminary reliability analysis. J Cult Herit 39:130-139

Rainieri C, Fabbrocino G, Verderame GM (2013) Non-destructive characterisation and dynamic identification of a modern heritage building for serviceability seismic analyses. NDT and E Int 60:17-31. https://doi.org/10.1016/j.ndteint.2013.06.003

Ramírez E, Lourenço PB, D’Amato M (2019) Seismic Assessment of the Matera Cathedral. RILEM Bookseries, 18, Proceedings of SAHC 2018, 11th International Conference on Structural Analysis of Historical Constructions (Cusco, Perù, 11-13 September 2018). pp. 1346-1354

Sevieri G, Galasso C, D'Ayala D, De Jesus R, Oreta A, Grio MEDA, Ibabao R (2020) A multi-hazard risk prioritisation framework for cultural heritage assets. Nat Hazard 20(5):1391-1391

Silva V, Crowley H, Pagani M et al (2014) Development of the OpenQuake engine, the Global Earthquake Model's open-source software for seismic risk assessment. Nat Hazards 72:1409-1427

Silva V, Crowley H, Varum H et al (2015) Seismic risk assessment for mainland Portugal. Bull Earthq Eng 13:429-457

UNDRO (1980) Natural Disasters and vulnerability Analysis. In: Report of Experts Group Meeting, Geneva

Valluzzi M, Munari M, Modena C (2006) Analisi di aggregati complessi per valutazioni di vulnerabilità sismica: il caso di Castelluccio di Norcia. In: Binda L (ed) Sicurezza e conservazione degli edifici storici in funzione delle tipologie edilizie, della concezione costruttiva e dei materiali

Vicente R (2008) Strategies and methodologies for urban rehabilitation interventions. The vulnerability assessment and risk evaluation of the old city centre of Coimbra, $\mathrm{PhD}$ thesis, University of Aveiro

Vicente R, Parodi S, Lagomarsino S, Varum H, Silva JARM (2011a) Seismic vulnerability and risk assessment: case study of the historic city centre of Coimbra, Portugal. Bull Earthq Eng 9:1067-1096. https://doi.org/10.1007/s10518-010-9233-3

Vicente R, Parodi S, Lagomarsino S et al (2011b) Seismic vulnerability and risk assessment: case study of the historic city centre of Coimbra, Portugal. Bull Earthquake Eng 9:1067-1096

Wieland M, Pittore M, Parola S, Begaliev U, Yasunov P, Tyagunov S, Moldobekov B, Saidiy S, Ilyasov I, Abakanov T (2015) A Multiscale Exposure Model for Seismic Risk Assessment in Central Asia. Seismol Res Lett 86(1):210-222

Yang WS, Slejko D, Viezzoli D (1989) Seismic Risk in Friuli-Venezia Giulia: an approach. Soil Dyn Earthq Eng 8(2):96-105

Zuccaro G, Cacace F (2015) Seismic vulnerability assessment based on typological characteristics. The first level procedure "SAVE." Soil Dyn Earthq Eng 69:262-269

Zuccaro G, Papa F, Baratta A (2000) Aggiornamento delle mappe a scala nazionale di vulnerabilita sismica delle strutture edilizie La vulnerabilita degli edifici: valutazione a scala nazionale della vulnerabilita sismica degli edifici ordinari, edited by: Bernardini, A, Gruppo Nazionale per la Difesa dai Terremoti, Rome, Istituto Nazionale di Geofisica e Vulcanologia, Italy

Publisher's Note Springer Nature remains neutral with regard to jurisdictional claims in published maps and institutional affiliations. 